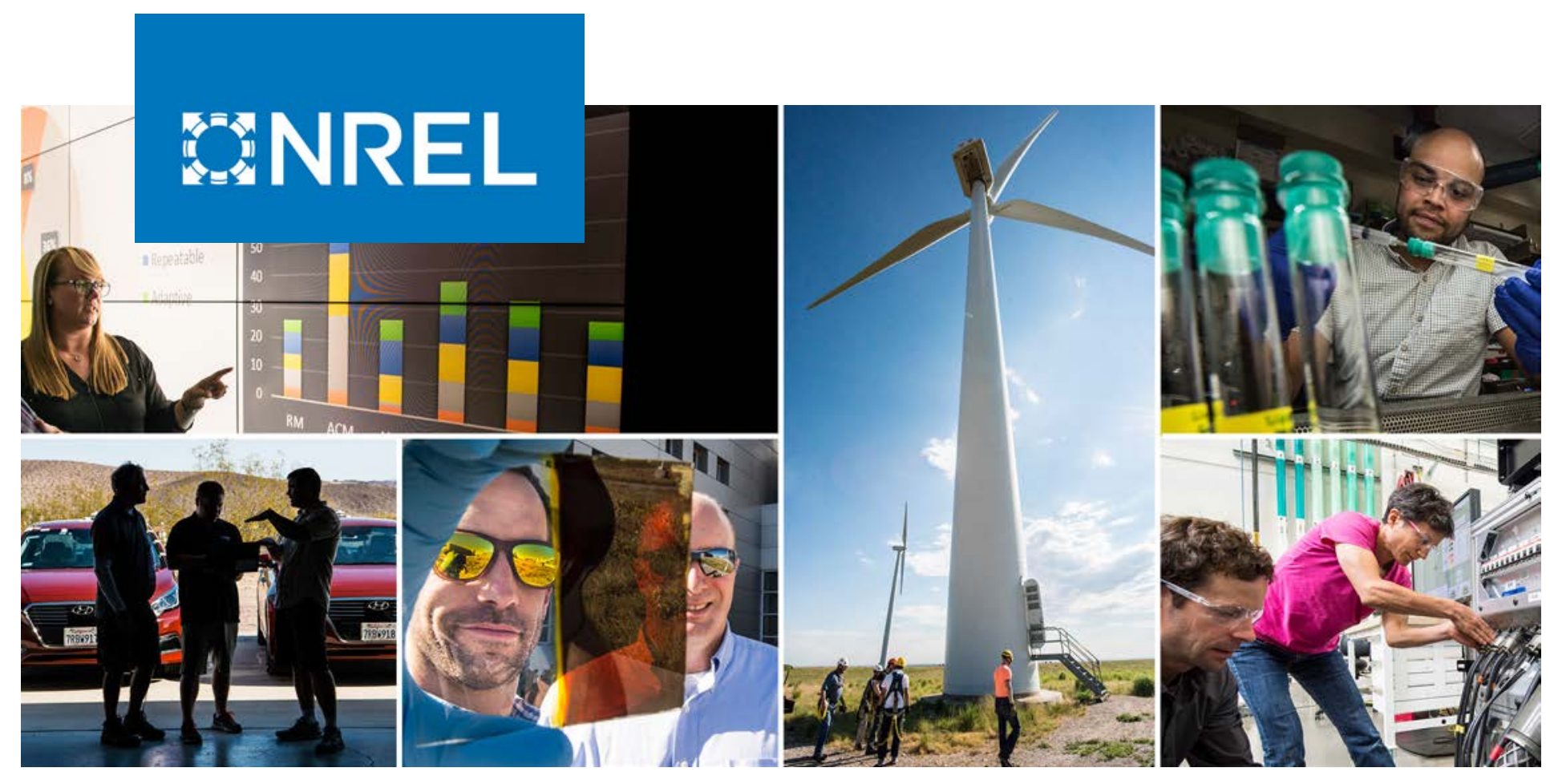

\title{
Analysis of the Cost and Value of Concentrating Solar Power in China
}

Ella Zhou, ${ }^{1}$ Kaifeng Xu, ${ }^{1}$ and Caixia Wang ${ }^{2}$

1 National Renewable Energy Laboratory

2 State Grid Energy Research Institute

NREL is a national laboratory of the U.S. Department of Energy

Office of Energy Efficiency \& Renewable Energy

Operated by the Alliance for Sustainable Energy, LLC

This report is available at no cost from the National Renewable Energy Laboratory (NREL) at www.nrel.gov/publications.
Technical Report

NREL/TP-6A20-74303

October 2019 


\title{
GNREL
}

\section{Analysis of the Cost and Value of Concentrating Solar Power in China}

\author{
Ella Zhou, ${ }^{1}$ Kaifeng Xu, ${ }^{1}$ and Caixia Wang ${ }^{2}$
}

1 National Renewable Energy Laboratory

2 State Grid Energy Research Institute

\section{Suggested Citation}

Zhou, Ella, Kaifeng Xu, and Caixia Wang. 2019. Analysis of the Cost and Value of Concentrating Solar Power in China. Golden, CO: National Renewable Energy

Laboratory. NREL/TP-6A20-74303. https://www.nrel.gov/docs/fy20osti/74303.pdf.

NREL is a national laboratory of the U.S. Department of Energy Office of Energy Efficiency \& Renewable Energy Operated by the Alliance for Sustainable Energy, LLC

This report is available at no cost from the National Renewable Energy Laboratory (NREL) at www.nrel.gov/publications.

Contract No. DE-AC36-08GO28308
Technical Report NREL/TP-6A20-74303 October 2019

National Renewable Energy Laboratory 15013 Denver West Parkway Golden, CO 80401

303-275-3000 • www.nrel.gov 


\section{NOTICE}

This work was authored in part by the National Renewable Energy Laboratory, operated by Alliance for Sustainable Energy, LLC, for the U.S. Department of Energy (DOE) under Contract No. DE-AC36-08GO28308. This report was funded under the U.S. China Renewable Energy Partnership through the U.S. Department of Energy. The study's modeling work is carried out under the China Program funded by the Children's Investment Fund Foundation in the United Kingdom. The views expressed herein do not necessarily represent the views of the DOE or the U.S. Government.

This report is available at no cost from the National Renewable Energy Laboratory (NREL) at www.nrel.gov/publications.

U.S. Department of Energy (DOE) reports produced after 1991 and a growing number of pre-1991 documents are available free via www.OSTI.gov.

Cover Photos by Dennis Schroeder: (clockwise, left to right) NREL 51934, NREL 45897, NREL 42160, NREL 45891, NREL 48097, NREL 46526.

NREL prints on paper that contains recycled content. 


\section{Acknowledgements}

This report was funded under the U.S. China Renewable Energy Partnership through the U.S. Department of Energy. The study's modeling work is carried out under the China Program funded by the Children's Investment Fund Foundation in the United Kingdom.

The authors would like to thank Guangdong Zhu, Janna Martinek, John Barnett, and Patricia Statwick of NREL, Zhifeng Wang and Alina Gilmanova of Chinese Academy of Science's Institute of Electrical Engineering, and Ershun Du of Tsinghua University for their reviews and comments. Any errors or omissions are solely the responsibility of the authors. 


\section{Table of Contents}

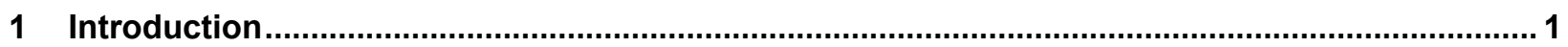

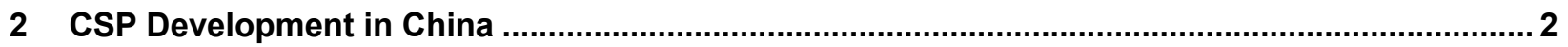

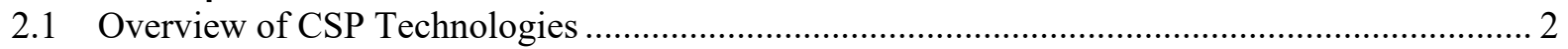

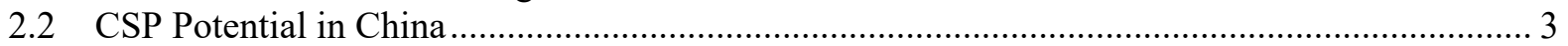

2.3 Policy Framework and Financial Incentives for CSP Development and Innovation in China ..... 4

3 Levelized Cost of Energy Analysis of CSP Systems in China ..................................................... 5

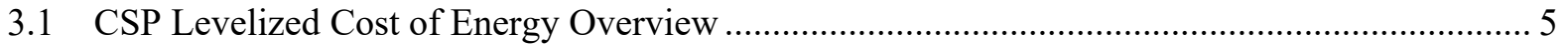

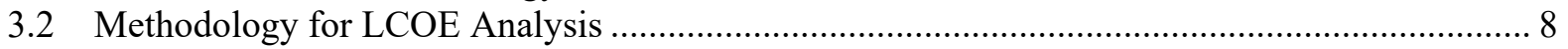

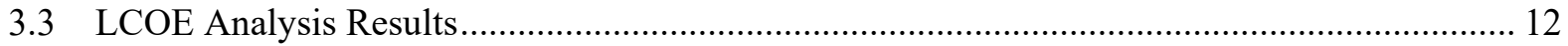

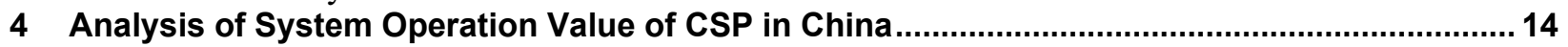

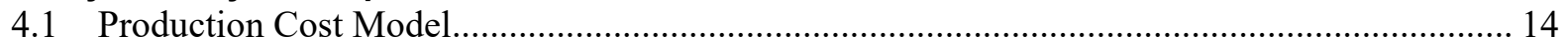

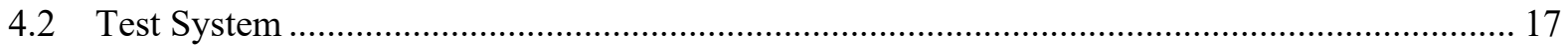

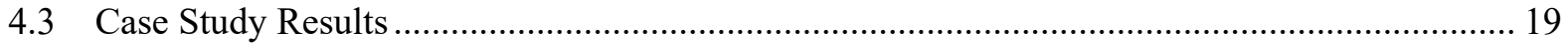

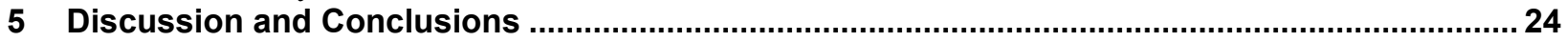

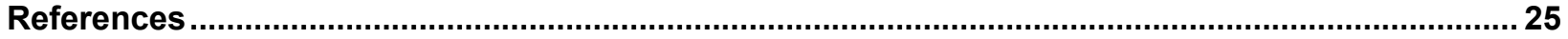




\section{List of Figures}

Figure 1. Cumulative installed CSP capacity by country/region ...................................................... 1

Figure 2. Installed and planned CSP capacity in China ...................................................................... 3

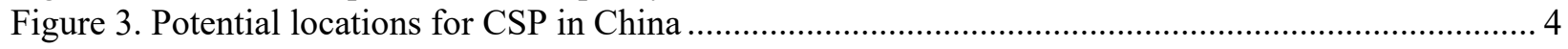

Figure 4. LCOEs of current existing or simulated CSP projects in the reviewed literature ........................ 7

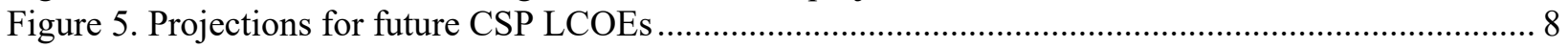

Figure 6. Capacity factors of simulated parabolic trough plant (left) and LCOEs of simulated parabolic

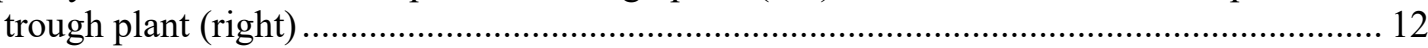

Figure 7. Capacity factors of simulated molten salt power tower plant (left) and LCOEs of simulated molten salt power tower plant (right) ......................................................................... 13

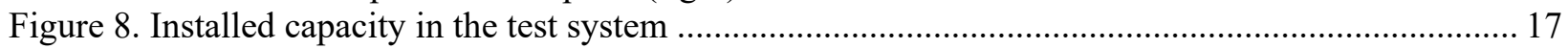

Figure 9. Generation stack of Reference Case (SM=1.6, $\mathrm{H}=4$, left) and Cases 2-5, generation difference

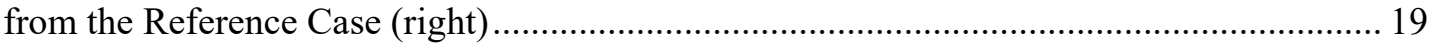

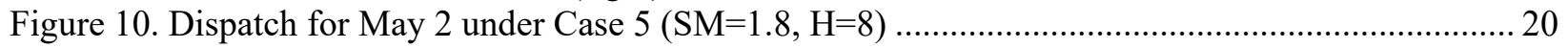

Figure 11. Coal long-term (LT) unit commitment and short-term economic dispatch under Case 3

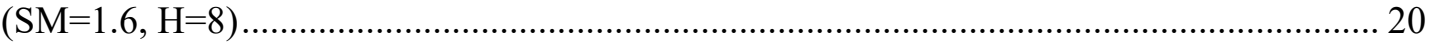

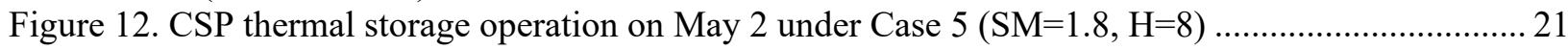

Figure 13. Annual curtailment averaged to the hour of the day for the Reference Case .......................... 22

Figure 14. Difference in total curtailment from the Reference Case ..................................................... 22

\section{List of Tables}

Table 1. Taxes and Potential Fees for CSP Projects in China ............................................................... 9

Table 2. Cost Inputs Used for SAM Simulation, Compared with the SAM Reference Case Parabolic

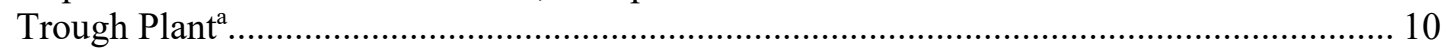

Table 3. Conventional (Coal) Generators in the Test System............................................................. 18

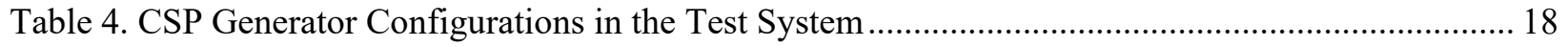

Table 5. CSP Generator Properties in the Test System........................................................................ 19

Table 6. Impact on Total System Operation Cost and Renewable Energy Curtailment ............................ 23 


\section{Introduction}

Concentrating solar power (CSP) is considered an attractive technology in many parts of the world because it can be equipped with low-cost thermal energy storage to provide dispatchable renewable energy and offer flexibility to a national grid. It can also produce significant amounts of varying-temperature heat for industrial processes, and it can be used for water desalination in arid countries with abundant solar resources. Currently, a total of $5.43 \mathrm{GW}$ of CSP is deployed worldwide, with $2.30 \mathrm{GW}$ (42.48\%) deployed in Spain and $1.88 \mathrm{GW}(34.65 \%)$ in the United States (Figure 1). The International Energy Agency estimates that by 2050, with appropriate support, CSP could provide $11.3 \%$ of global electricity (IEA 2010). China had a later start on CSP development, but the growing demand for dispatchable renewable energy is driving the interest in developing CSP there. In its 13th Five Year Plan, China sets a goal of deploying 5 GW of CSP by 2020 (NEA 2016). According to a study from China Renewable Energy Institute, CSP deployment in China is projected to reach $30 \mathrm{GW}$ by 2030 and $180 \mathrm{GW}$ by 2050 , compared with total installed capacity of 251.65 MW as of September 2019 (CRES 2013).

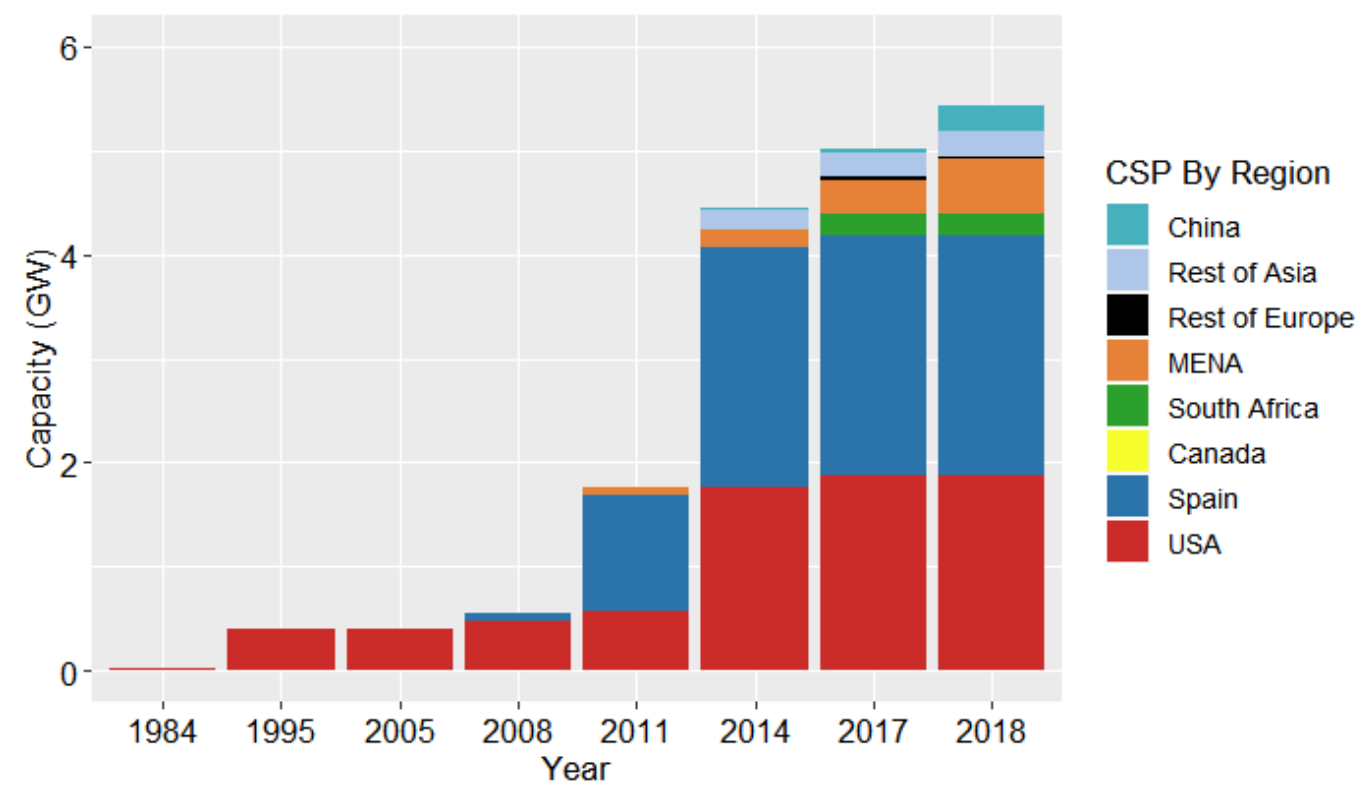

Figure 1. Cumulative installed CSP capacity by country/region

MENA = Middle East and North Africa

Sources: SolarPACES and CSPPLAZA.

As CSP is an emerging technology in China, its cost and value are not very well understood. This study provides the context of CSP development in China, as well as the basic data and methods for analyzing CSP in the power system. Since China does not have established power markets in the region we analyzed, our value analysis focuses on the impact to system operation cost, even though CSP offers a range of values, including capacity, energy, and ancillary services. The report is divided into five parts. Following the introduction, we provide an overview of CSP technologies and potentials in China, and the policy and regulatory environment for CSP development (Section 2). Then we conduct a literature review of levelized cost of energy (LCOE) estimations for CSP and use the System Advisor Model to analyze the LCOEs for CSPs in China with different configurations of solar multiples and hours of storage, 
where the solar multiple is the ratio of the thermal power produced by the solar field to that required by the power block at design point (Section 3). We use an economic dispatch model to analyze the hourly system operations with different configurations of CSP (Section 4). Finally, we conclude the report with areas for further research (Section 5).

\section{CSP Development in China}

\subsection{Overview of CSP Technologies}

CSP uses high specular reflectors (typically mirrors) to concentrate solar radiation to produce high-temperature heat and generate electricity through a thermodynamic cycle. One example is a CSP solar field that heats the thermal oil, generates steam through a heat exchanger, and produces electricity by using steam to drive a steam turbine electricity generator. Two main types of CSP technologies are currently deployed: (1) line-focusing systems such as parabolic trough and linear Fresnel technology and (2) point-focusing systems such as power tower and dish Stirling-engine technology.

Point-focusing collectors can have a higher concentration ratio than line-focus collectors. Parabolic trough technology is dominating the current commercial CSP market and power tower technology is treated as the next-generation emerging technology. Power tower technology can enable higher-temperature heat generation with a compact receiver component and thus result in a lower-cost energy storage system and higher-efficiency thermodynamic cycle. Generally, parabolic trough technology has a higher annual optical efficiency than power tower technology (Kincaid et al. 2018). Currently, the U.S. CSP research is focused on power towers, mainly because of their higher possible operating temperatures and projected lower LCOE. Linear Fresnel technology typically has a lower optical efficiency and potentially lower cost, and it may be competitive combined with molten salt technologies and used in lower-temperature process heat applications (Qiu et al. 2015; Gabbrielli et al. 2014). Dish Stirling-engine technology has the highest optical efficiency of all CSP technologies, but it suffers from higher system costs and difficulties in integrating with large-scale energy storage systems. Figure 2 shows the amount of installed and planned CSP projects in China by technology. As illustrated in the figure, the development of CSP was slow in China before 2018, but exponential growth is expected in 2019 and 2020. Most of the deployed and planned systems are power tower and parabolic trough technologies, which are the focus of this report. 


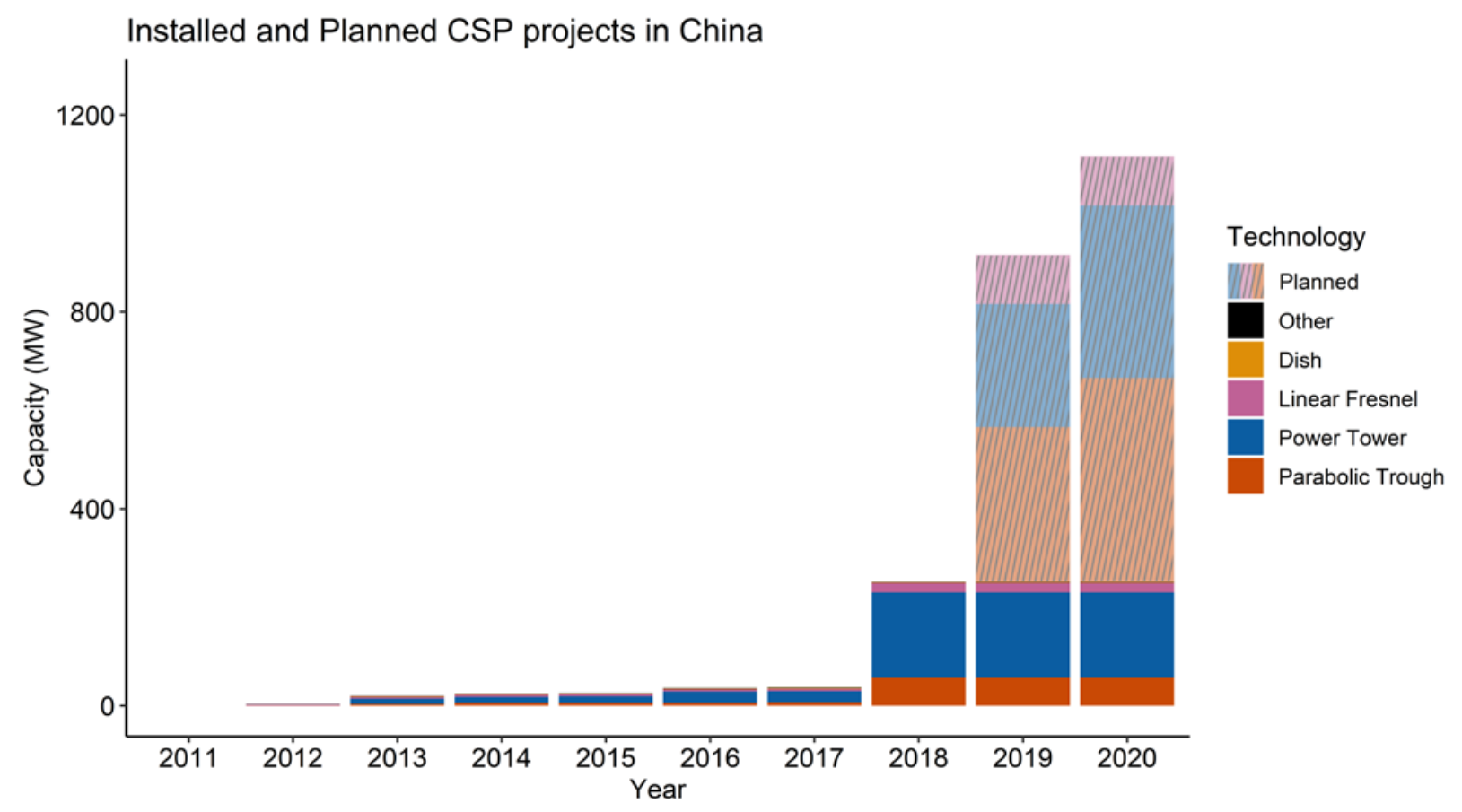

Figure 2. Installed and planned CSP capacity in China

Dashed bars indicate planned capacities and the year they are expected to be online.

\subsection{CSP Potential in China}

Several factors, including solar resource, land resource, water resource, and power grid access influence the potential for CSP development. A typical CSP plant requires a minimum direct normal irradiance (DNI) of $5 \mathrm{kWh} / \mathrm{m}^{2}$ per day (J. Wang et al. 2017) and up to $20,000 \mathrm{~m}^{2}$ of land per thermal megawatt at the design point due to the size of its solar field (Hou et al. 2009). Several studies on CSP potential have been conducted for China, but at a relatively coarse resolution. Research from the Chinese Academy of Sciences (2009) based on NREL's 40-km by $40-\mathrm{km}$ DNI data estimates there is a total of $16,000 \mathrm{GW}$ of CSP capacity potential in China, $1,400 \mathrm{GW}$ of which are in places with DNI equal to or greater than $7 \mathrm{kWh} / \mathrm{m}^{2}$ per day. The total generation potential from CSP technologies in China is estimated to be 42,000 terawatthours/year (ibid). This is generally consistent with a study (Ummel 2010) based on the European Space Agency's GlobCover product, which puts potential CSP outputs in China at 51,133 terawatt-hours/year.

In terms of resource pockets, southeastern Tibet, southern Xinjiang, eastern Qinghai, central Gansu, and Inner Mongolia have the best solar radiation resources (Chen, Li, and Wu 2010). Excluding densely populated areas (i.e., those with more than 150 persons per square kilometer), farming areas, protected nature preserves, sensitive ecosystems, as well as certain geomorphological features (e.g., sand dunes, rock outcrops, salt flats, glaciers, and slopes greater than 3\%), Li et al. (2014) find that locations suitable for CSP development are mainly in northern and northwestern China, as illustrated in Figure 3. However, these areas typically have limited water availability and grid access. 


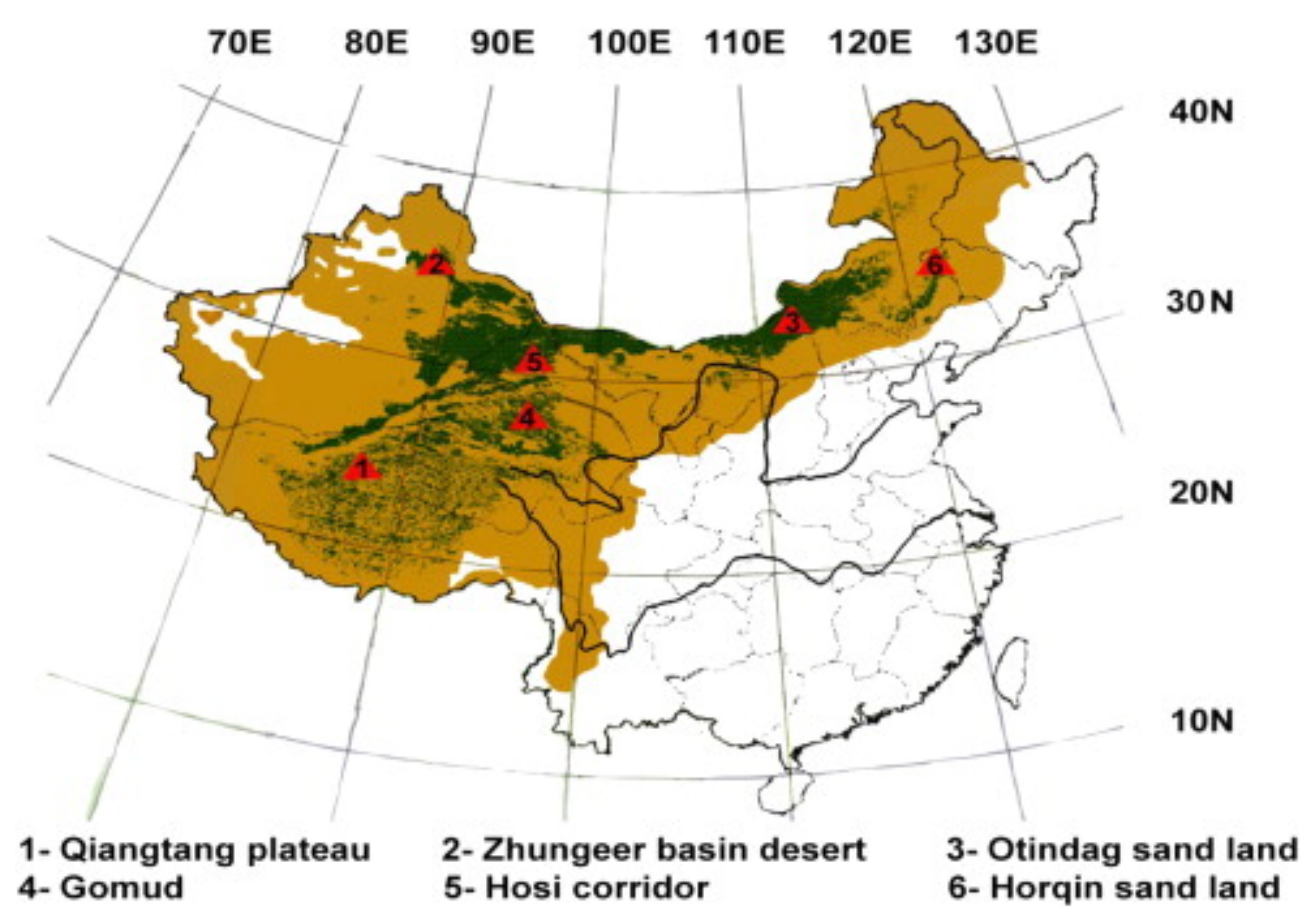

Figure 3. Potential locations for CSP in China (Li et al. 2014)

Green indicates potential CSP resource areas with land exclusions. Red triangles indicate most feasible locations as narrowed down by water and grid availability.

\subsection{Policy Framework and Financial Incentives for CSP Development and Innovation in China}

China has a policy framework for the development of CSP but very limited financial incentives. As mentioned, CSP is part of China's $13^{\text {th }}$ Five Year Plan for energy. And CSP is included in China's Guidance Catalogue for Industrial Structure Adjustment: 2011-2015, which the State Council released in 2012. CSP is also a part of China Manufacturing 2025: Energy Equipment Implementation Plan, which highlights the importance of completing field demonstrations of core CSP technologies. Multiple CSP components and technologies have been included as "strategic new industrial products and services" in a category released by China's National Development and Reform Commission (NDRC 2017) that is used to direct investments into specific industrial sectors and to enable more detailed accounting of the strategic sectors. In addition, CSP is included in China's new national Renewable Obligation Mechanism launched in May 2019, which requires each province to meet certain percentage of generation with nonhydro renewable sources.

China uses three major instruments to stimulate the development and innovation of CSP, including the auction scheme; feed-in tariffs; and research, development, and demonstration support. In very limited circumstances, CSP can receive preferential loans.

The auction scheme is the dominant instrument used to support CSP deployment internationally, and it is implemented in many countries, including Australia, Chile, China, Morocco, South Africa, and United Arab Emirates. Auctions are effective in driving down costs but could risk the financial viability of the winning entity. Since the first tender in October 2010 for a 50-megawatt 
(MW) CSP plant in Inner Mongolia, China has announced several CSP tenders. The early winners are dominantly state-owned enterprises, but as the industry grows, more private companies have entered the CSP business in China.

The second policy instrument for stimulating CSP development in China is the feed-in tariff. It is recognized as an effective, albeit costly, measure to boost renewable technology deployment. For example, the Spanish feed-in tariff, started in 2008, triggered almost 50 CSP plants. It hardly led to the optimal use of thermal storage however, because storage was not part of the Spanish feedin tariff (Lilliestam et al. 2018). China's National Energy Administration established a benchmark feet-in tariff of $\$ 0.172 / \mathrm{kWh}^{1}$ for CSP in 2017. Due to the slow progress of CSP development in China, the feed-in tariff, which was originally eligible for projects put into operation before the end of 2018, may be extended to projects built before the end of 2020 at a reduced amount.

In terms of research, development, and demonstration support, the Ministry of Science and Technology and the National Energy Administration have established a series of CSP research and demonstration projects. Participants in these projects include research institutes (e.g., the Institute of Electrical Engineering at the Chinese Academy of Sciences, China Electric Power Planning and Engineering Institute, China Renewable Energy Engineering Institute, Peking University, and Shanghai Jiaotong University), organizations such as China National Solar Thermal Energy Alliance, and state-owned as well as private companies. The first 20 CSP demonstration projects were approved in September 2016, but since then, many of them have experienced delays and four of them have been cancelled. By August 2019, three CSP plants were in operation in China. The 50-MW China General Nuclear Power Group project at Delingha, which began operating on October 10, 2018, was the first among the 20 demonstration CSP projects in China.

CSP receives few financial incentives beyond the three main drivers. Preferential loans are available only to a very limited number of CSP projects. The 50-MW Delingha project, for instance, received $47 \%$ of the necessary capital as a preferential loan from the Asian Development Bank at the interest rate of 3\%. In comparison, the interest rate on a commercial loan is $6.345 \%$ as of 2017 (Zhao, Chen, and Thomson 2017).

Despite the policy support, the development of CSP in China has been slow - and is attributed to the high cost of CSP systems and the lack of assessment of the value CSP provides to the power system (CSP Plaza 2019). Therefore, this report aims to provide a better understanding of the cost and value of CSP in China.

\section{Levelized Cost of Energy Analysis of CSP Systems in China}

\subsection{CSP Levelized Cost of Energy Overview}

The most frequently used metric for analyzing the cost of a given power generation technology is the levelized cost of electricity (LCOE). It is generally calculated as the amortized capital and

${ }^{1} 1.15$ RMB at an exchange rate on September 1, 2016 of $\$ 1=$ RMB 6.679 
operating costs divided by the electricity produced over the lifetime of the plant. However, different LCOE calculation methods may include or exclude certain factors such as insurance, taxes, interest during construction, decommissioning costs, and financial incentives, which could influence the calculated value. As a result, an LCOE comparison can help shed light on the general range of costs for a certain technology; it is not to be used as a precise prediction of cost.

We reviewed a range of CSP LCOE calculations in the literature since 2000. The LCOEs of existing or simulated CSP projects by technology are shown in Figure 4, and projections for future CSP LCOE trends are shown in Figure 5. Parabolic trough and power tower systems are the most examined CSP technologies in the literature. As seen from Figure 4, parabolic trough technology has a slightly lower LCOE (between $\$ 144.4$ per megawatt-hours (MWh) and $\$ 296.2 / \mathrm{MWh}$ for the middle 50th percentile) than power tower technology (between $\$ 176.6 / \mathrm{MWh}$ and $\$ 306.7 / \mathrm{MWh}$ for the middle 50th percentile) for existing units. The width of the bars in the figures indicates the uncertainty in costs in the simulated studies. For projections of future LCOEs, the estimates for parabolic trough technology are higher than the estimates for power tower technology (Figure 5); this is because in the long term, the higher operating temperature of the power tower gives it an efficiency and cost advantage over parabolic troughs (Turchi et al. 2010). Most studies expect the LCOEs of both technologies to drop to around $\$ 100 /$ MWh by 2020 (e.g., (Sargent \& Lundy 2003; Z. Wang 2010)). Though this is still higher than solar PV, CSP can offer much higher capacity factors and the thermal energy storage can provide system services that are becoming increasingly crucial and valuable with highpenetration renewables. 


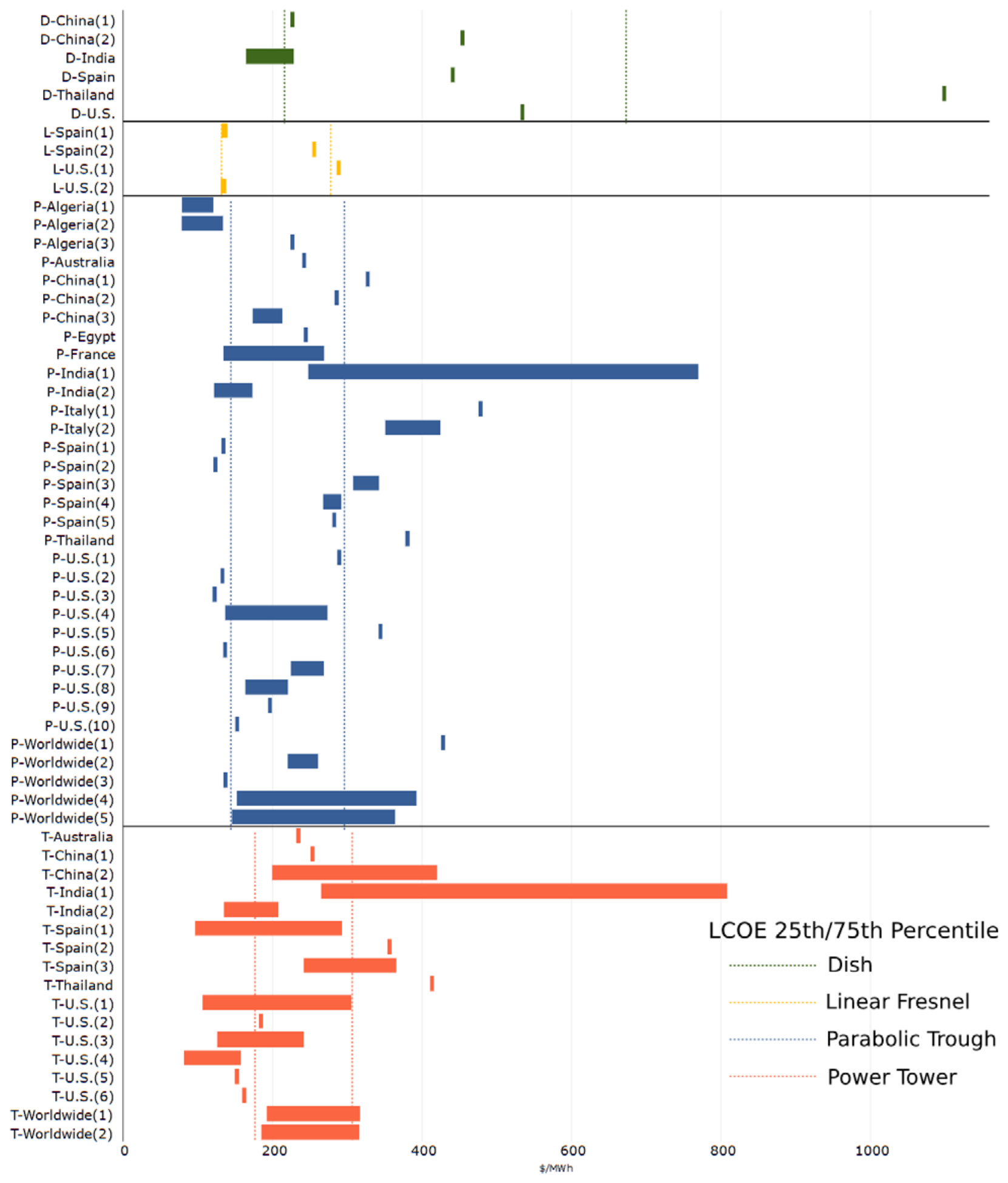

Figure 4. LCOEs of current existing or simulated CSP projects in the reviewed literature

Technology and country are indicated on the $Y$-axis, where $D=$ dish Stirling, $\mathrm{L}=$ linear Fresnel, $\mathrm{P}=$ parabolic trough, and $\mathrm{T}=$ power tower.

A full list of references used in this figure is in Appendix A. 


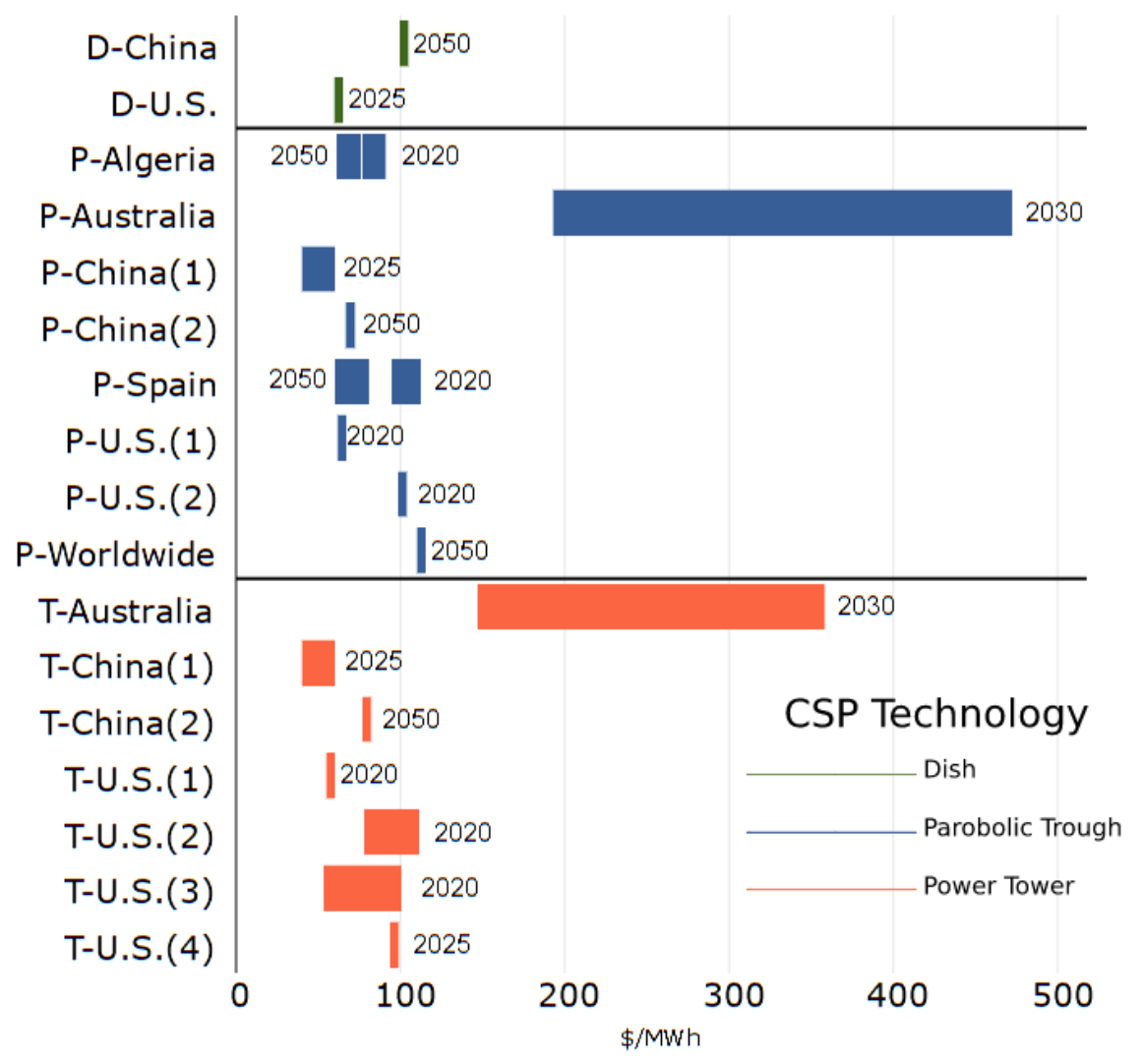

Figure 5. Projections for future CSP LCOEs

Technology and country are indicated on the $\mathrm{Y}$-axis, where $\mathrm{D}=$ dish Stirling, $\mathrm{P}=$ parabolic trough, and $\mathrm{T}=$ power tower.

The year listed is the projection year. A full list of references used in this figure is in Appendix B.

\subsection{Methodology for LCOE Analysis}

This study uses the System Advisor Model (SAM), which was developed by the National Renewable Energy Laboratory (NREL), to analyze the LCOEs of different configurations of parabolic trough and power tower CSP systems in China. SAM is a system analysis model for assessing the performance and costs of grid-connected power projects based on user-defined installation and operating costs and system design parameters (Blair et al. 2018). It has been used in several studies reviewed above (Turchi et al. 2010, Pierce et al. 2013, Parrado et al. 2016).

This section focuses on the cost of parabolic trough and power tower technologies, because as shown in Figure 2, they are the two dominant CSP technologies in China. Only dry cooled CSP is examined for this study, because the National Energy Administration has required all CSP demonstration projects to be dry-cooling due to water constraints in northwestern China.

Our SAM simulation is based on a site in Delingha, Qinghai province (latitude: 37.29, longitude: 96.751). The typical meteorological year data (2007-2016) are obtained from European Commission's Photovoltaic Geographical Information System. A total of 200 simulations are 
run, including a set of 100 simulations for a parabolic trough plant and another set of 100 simulations for a molten salt power tower plant. Each set contains different configurations of solar multiple (SM) and hours of storage. Solar multiples range from 1.0 to 2.8, and hours of storage range from 1 hour to 16 hours. We keep the thermal rating of the power block fixed for the sensitivity analysis, and we vary the size of the heliostat field for each simulation. We calculate the unsubsidized LCOE (i.e., not including the current feed-in tariff) for better comparison with international results.

Cost input is critical to our LCOE analysis. Real cost data for CSP projects in China are difficult to obtain because of concerns about business confidentiality, so the data are mainly obtained through the literature and vetted by the authors' best judgment and reviewers' input. CSP projects in China are subject to a substantial list of taxes and fees that could be different case by case. Table 1 lists some of the taxes and fees tow which a CSP project in China may be subject.

Table 1. Taxes and Potential Fees for CSP Projects in China ${ }^{a}$

\begin{tabular}{|c|c|c|}
\hline Type & Rate & Note \\
\hline Income tax & $25 \%{ }^{[1]}$ & $\begin{array}{l}\text { For government investment } \\
\text { authority verified project, could get } \\
\text { tax exemption for years } 1-3 \text { and } \\
50 \% \text { reduction for years } 4-6^{[2,3]}\end{array}$ \\
\hline Value-added tax (VAT) & $16 \%{ }^{[4]}$ & Was $17 \%$ before April 30, $2018^{[5]}$ \\
\hline VAT surcharge & $\begin{array}{l}7 \% \text { of VAT for city construction } \\
3 \% \text { of VAT for education } \\
2 \% \text { of VAT for local education }{ }^{[6]} \\
\text { No VAT surcharges for foreign } \\
\text { enterprises in China }\end{array}$ & $\begin{array}{l}\text { Categories and amount of } \\
\text { surcharge can vary by province } \\
\text { and location }\end{array}$ \\
\hline Land use tax & $\begin{array}{l}\text { Farmland occupancy tax: } 5-30 \\
\text { RMB } / \mathrm{m}^{2}\left(0.74-4.44 \$ / \mathrm{m}^{2}\right) \text { in } \\
\text { Qinghai Province }{ }^{[7]}\end{array}$ & Vary by province and location \\
\hline Land acquisition fee & $\begin{array}{l}\text { 3-40 RMB } / \mathrm{m}^{2}\left(0.44-5.92 \$ / \mathrm{m}^{2}\right) \text { in } \\
\text { Delingha, Qinghai Province }{ }^{[8]}\end{array}$ & Vary by province and location \\
\hline Pension insurance fee & $\begin{array}{l}\text { 1.36 RMB } / \mathrm{m} 2\left(\$ 0.20 / \mathrm{m}^{2}\right) \text { or } 50 \% \\
\text { of land acquisition fee } \mathrm{e}^{[\mathrm{g}, 10]}\end{array}$ & Vary by province and location \\
\hline Grassland restoration fee & $5.54 \mathrm{RMB} / \mathrm{m} 2\left(\$ 0.82 / \mathrm{m}^{2}\right)^{[9]}$ & $\begin{array}{l}\text { Vary by province and location; this } \\
\text { fee is currently suspended for } \\
\text { solar PV projects in Qinghai } \\
\text { Province }{ }^{[11]}\end{array}$ \\
\hline $\begin{array}{l}\text { Water and soil conservation } \\
\text { and restoration fee }\end{array}$ & $1.5 \mathrm{RMB} / \mathrm{m} 2\left(0.22 \$ / \mathrm{m}^{2}\right)^{[12]}$ & Vary by province and location \\
\hline
\end{tabular}

a Sources for all figures in the table are listed in Appendix C.

In the LCOE assessment, the taxes and fees are simplified and added to the corresponding land cost or variable costs. The main cost inputs for CSP simulations are summarized in Table 2. One caveat is that very limited data on the costs of CSP projects in China are publicly available, so our cost input assumptions are collected from a few different studies and are therefore not always consistent with each other. We use our judgment to choose data that seem reasonable for 
our simulation analysis to show the cost trends for different technical configurations, but these data do not represent the real cost of any specific CSP projects in China.

From the data we have collected, CSP plants in China generally have lower capital costs for conventional components (e.g., heliostat field mirrors, piping and insulation, steam turbine generators, the cooling system, and the condensate system) and lower labor costs for plant operation and maintenance. But China has higher project and land management costs, which may reflect some local administration burdens on project developers.

Table 2. Cost Inputs Used for SAM Simulation, Compared with the SAM Reference Case Parabolic Trough Plant ${ }^{\mathrm{a}}$

\begin{tabular}{|c|c|c|c|c|c|}
\hline Category & Units & $\begin{array}{l}\text { Default SAM } \\
\text { Value for } \\
\text { Parabolic } \\
\text { Trough } \\
(100-M W)\end{array}$ & $\begin{array}{l}\text { Simulated } \\
\text { Chinese } \\
\text { Parabolic } \\
\text { Trough } \\
(100-\mathrm{MW}) \\
\end{array}$ & $\begin{array}{l}\text { Default SAM } \\
\text { Value for } \\
\text { Power Tower } \\
(100-M W)\end{array}$ & $\begin{array}{l}\text { Simulated } \\
\text { Chinese Molten } \\
\text { Salt Power } \\
\text { Tower } \\
(100-M W)\end{array}$ \\
\hline \multicolumn{6}{|l|}{ Direct Costs } \\
\hline Site improvements & $\$ / \mathrm{m} 2$ & $30^{[1]}$ & $12.59^{[2]}$ & $16^{[3]}$ & $12.59^{[2]}$ \\
\hline Heliostat field cost & $\$ / \mathrm{m} 2$ & - & - & $145^{[3]}$ & $92.78^{[2]}$ \\
\hline $\begin{array}{l}\text { Heliostat field } \\
\text { cost, fixed }\end{array}$ & $\$$ & - & - & - & $1,385,271.13^{[2]}$ \\
\hline Tower cost, fixed & $\$$ & - & 一 & $25,319,024^{[12]}$ & $12,467,440.21^{[2]}$ \\
\hline Receiver & $\$$ & - & - & $85,192,128^{[3]}$ & $8,311,626.81^{[2]}$ \\
\hline Solar field & $\$ / \mathrm{m} 2$ & $170^{[1]}$ & $124.20^{[5]}$ & 一 & - \\
\hline $\begin{array}{l}\text { Heat transfer } \\
\text { fluid system }\end{array}$ & $\$ / \mathrm{m} 2$ & $70^{[1]}$ & $28.88^{[5]}$ & - & - \\
\hline $\begin{array}{l}\text { Thermal energy } \\
\text { storage }\end{array}$ & $\$ / k W h t$ & $75^{[1]}$ & $22.08^{[5]}$ & $24^{[3]}$ & $36.18^{[2]}$ \\
\hline Fossil backup & $\$ / \mathrm{kWe}$ & $0^{[6]}$ & 0 & $0^{[4]}$ & 0 \\
\hline Power plant & $\$ / \mathrm{kWe}$ & $1,150^{[1]}$ & $287.91^{[7]}$ & $1,100^{[3]}$ & $306.88^{[2]}$ \\
\hline $\begin{array}{l}\text { Balance-of-plant } \\
\text { cost }\end{array}$ & $\$ / k W e$ & $120^{[1]}$ & $132.87^{[7]}$ & $340^{[3]}$ & $81.84^{[2]}$ \\
\hline \multicolumn{6}{|l|}{ Indirect Costs } \\
\hline Contingency & $\begin{array}{l}\% \text { of direct } \\
\text { cost }\end{array}$ & $7^{[1]}$ & $7^{[12]}$ & $7^{[1]}$ & $7^{[12]}$ \\
\hline $\begin{array}{l}\text { Engineering, } \\
\text { procurement, and } \\
\text { construction }\end{array}$ & $\begin{array}{l}\% \text { of direct } \\
\text { cost }\end{array}$ & $11^{[1]}$ & $11^{[1]}$ & $13^{[3]}$ & $13^{[3]}$ \\
\hline $\begin{array}{l}\text { Project and land } \\
\text { management }\end{array}$ & & $3.5 \%[6]$ & $\begin{array}{r}4,873,490.40 \\
\$^{[7]}\end{array}$ & $\begin{array}{r}10,000 \\
\$ / \text { acre }^{[4]}\end{array}$ & $\begin{array}{r}88,042.92 \\
\$ / \text { acre }^{[2]}\end{array}$ \\
\hline Fixed annual cost & $\$ / y r$ & $0^{[6]}$ & $0 \%{ }^{[2]}$ & $0^{[4]}$ & $0 \%{ }^{[2]}$ \\
\hline $\begin{array}{l}\text { Fixed cost by } \\
\text { capacity }\end{array}$ & $\$ / k W-y r$ & $66^{[1]}$ & $43.35^{[8]}$ & $66^{[3]}$ & $55.49^{[2]}$ \\
\hline
\end{tabular}




\begin{tabular}{|c|c|c|c|c|c|}
\hline Category & Units & $\begin{array}{l}\text { Default SAM } \\
\text { Value for } \\
\text { Parabolic } \\
\text { Trough } \\
(100-M W)\end{array}$ & $\begin{array}{l}\text { Simulated } \\
\text { Chinese } \\
\text { Parabolic } \\
\text { Trough } \\
(100-M W)\end{array}$ & $\begin{array}{l}\text { Default SAM } \\
\text { Value for } \\
\text { Power Tower } \\
(100-M W)\end{array}$ & $\begin{array}{l}\text { Simulated } \\
\text { Chinese Molten } \\
\text { Salt Power } \\
\text { Tower } \\
(100-M W)\end{array}$ \\
\hline $\begin{array}{l}\text { Variable cost by } \\
\text { generation }\end{array}$ & $\$ / M W h$ & $3^{[6]}$ & $2.29^{[7]}$ & $3.5^{[3]}$ & $3.54^{[2]}$ \\
\hline $\begin{array}{l}\text { Internal rate of } \\
\text { return target }\end{array}$ & $\%$ & $15^{[6]}$ & $8^{[7]}$ & $11^{[12]}$ & $8^{[7]}$ \\
\hline $\begin{array}{l}\text { Internal rate of } \\
\text { return target year }\end{array}$ & $\mathrm{yr}$ & 20 & $13^{[7]}$ & $20^{[12]}$ & $13^{[7]}$ \\
\hline Analysis period & $\mathrm{yr}$ & $30^{[10]}$ & $30^{[7]}$ & $30^{[10]}$ & $30^{[2]}$ \\
\hline Inflation rate & $\% / y r$ & $2.5^{[10]}$ & $1.6^{[11]}$ & $2.5^{[10]}$ & $1.6^{[11]}$ \\
\hline Real discount rate & $\% / y r$ & $8^{[10]}$ & $9^{2}$ & $8^{[10]}$ & 9 \\
\hline Debt percent & $\begin{array}{l}\text { percent of } \\
\text { total capital } \\
\text { cost }\end{array}$ & $54^{[10]}$ & $80^{[7]}$ & $54^{[10]}$ & $80^{[7]}$ \\
\hline Tenor & $\mathrm{yr}$ & NA & $13^{[7]}$ & $18^{[12]}$ & $13^{[7]}$ \\
\hline $\begin{array}{l}\text { Annual interest } \\
\text { rate }\end{array}$ & $\%$ & NA & $6.345^{[5]}$ & $7^{[12]}$ & $6.345^{[5]}$ \\
\hline Net salvage value & $\begin{array}{l}\text { percent of } \\
\text { installed } \\
\text { cost }\end{array}$ & $0^{[12]}$ & $5^{[7]}$ & $0^{[12]}$ & $5^{[7]}$ \\
\hline Depreciation & $\mathrm{yr}$ & 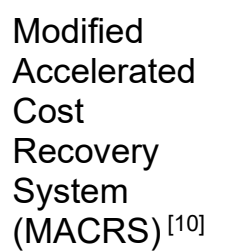 & $15^{[7]}$ & $\operatorname{MACRS}^{[10]}$ & $15^{[7]}$ \\
\hline
\end{tabular}

a Sources for all figures in the table are listed in Appendix D.

$\mathrm{kWht}=$ kilowatt-hour-thermal; $\mathrm{kWe}=$ kilowatt-electric

${ }^{2}$ A real discount rate of $9 \%$ is used to reflect the barrier to CSP investment in China, which is in the range of assumed discount rates used by several studies, including (International Renewable Energy Agency (IRENA) 2012; Hinkley et al. 2011; IEA 2010). All costs converted from the publication year currency to 2017 US dollars. 


\subsection{LCOE Analysis Results}

The general trends observed in the LCOE results of the simulated Chinese CSP plants are consistent with those in the non-Chinese literature (Madaeni, Sioshansi, and Denholm 2013; Jorgenson et al. 2013), but offer several new insights. The results (Figure 6 and 7) confirm that adding to the solar multiplier can increase the utilization of the power block and thereby raise the capacity factor of the CSP plant, but only to a limited degree if the storage capacity is constrained. Because increasing both the solar multiplier and storage increases the overall capital cost of the plant, simulations are needed to identify the configuration with the lowest LCOE. The lowest LCOEs for a 100-MW CSP plant in the selected Delingha location are achieved through $2 \mathrm{SM}$ with 4 hours of storage to $2.4 \mathrm{SM}$ with 8 hours of storage for a trough plant and $1.8 \mathrm{SM}$ with 6 hours of storage to $2.2 \mathrm{SM}$ with 8 hours of storage for a tower plant.
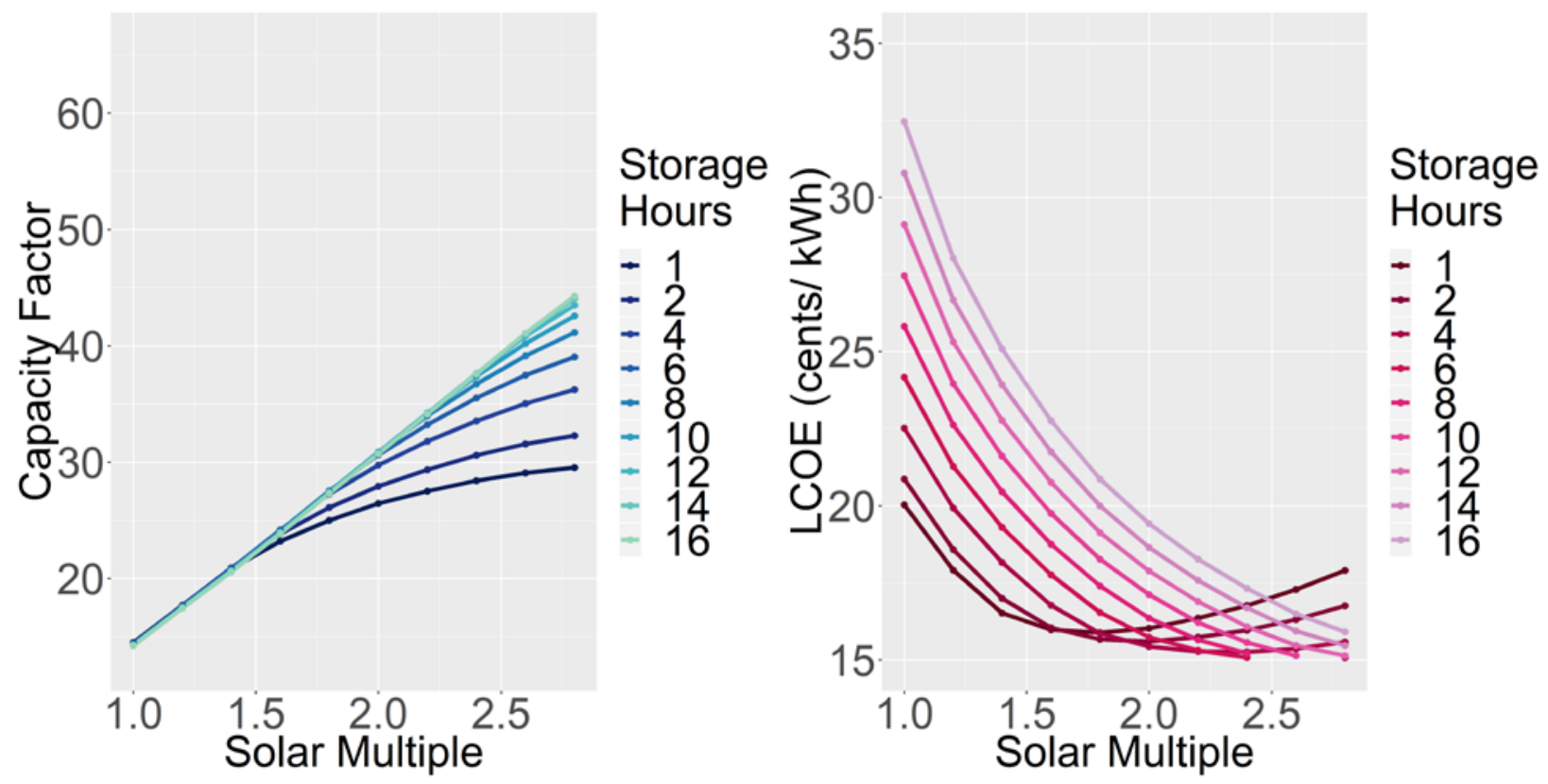

Figure 6. Capacity factors of simulated parabolic trough plant (left) and LCOEs of simulated parabolic trough plant (right) 


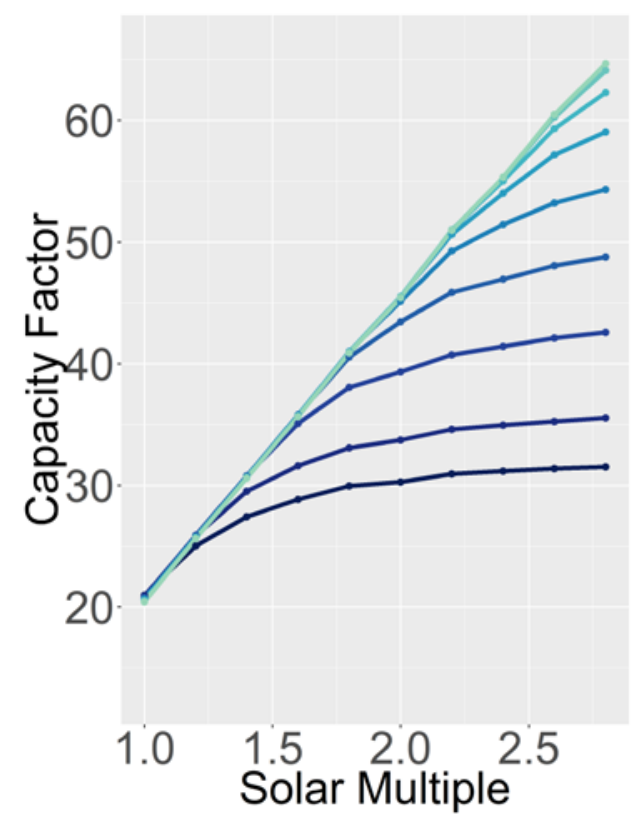

\section{5}
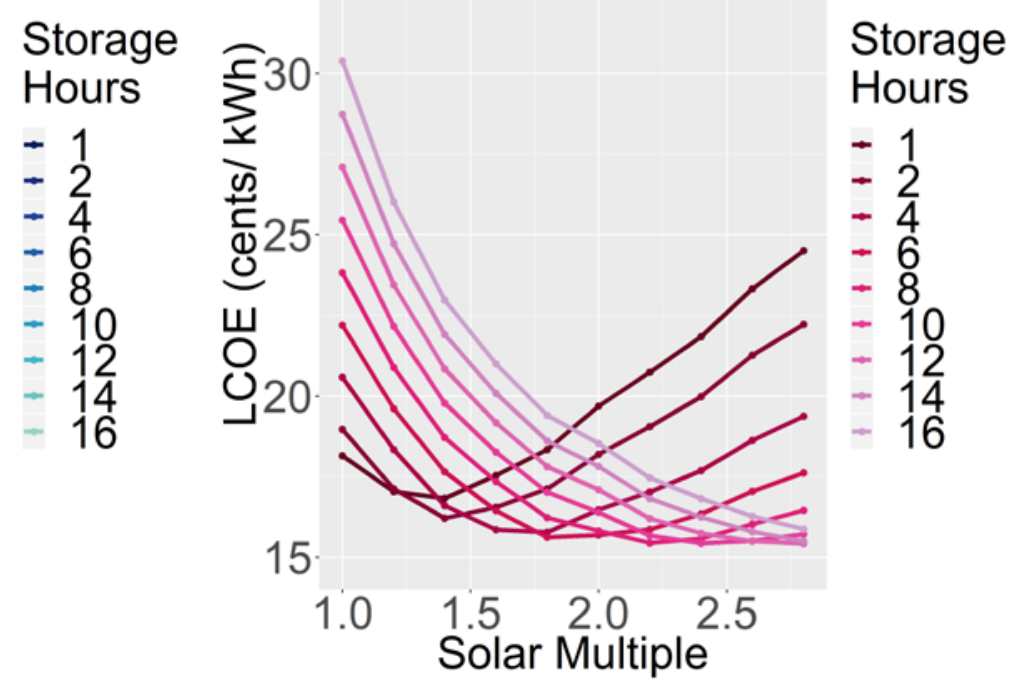

Figure 7. Capacity factors of simulated molten salt power tower plant (left) and LCOEs of simulated molten salt power tower plant (right)

Because the obtained data show lower solar resource in the selected Chinese region than typical CSP sites in the United States, the capacity factors of the simulated CSP plants in China are significantly lower than those in U.S. locations. The annual average DNI in the selected Delingha location is $6.0 \mathrm{kWh} / \mathrm{m}^{2} /$ day. In comparison, a southwestern U.S. location such as Daggett, California, has an average DNI of $7.7 \mathrm{kWh} / \mathrm{m}^{2} /$ day. Granted, better resources may be found in other locations in the Qinghai region, but we are limited by data availability. Nevertheless, with the data available, we can observe the capacity factor trends for different technologies. The tower plant has a higher capacity factor than the trough plant, and it is more significantly augmented by the increase in storage hours. With 6 hours of storage and SM of 2, the parabolic trough plant only has a capacity factor of $30.62 \%$ whereas the tower plant can reach a capacity factor of $43.44 \%$.

The cost and financial data for the Chinese tower plants results in a lower solar multiple for the lowest LCOE compared with similar study of a simulated U.S. CSP plant (Jorgenson et al. 2013). Results show the LCOE of a parabolic trough plant in China can reach around 15.2 cents/kWh with SM of 2.4 and 8 hours of storage. The LCOE of a tower plant can reach around 15.6 cents/kWh with SM of 1.8 and 6 hours of storage. The exact numbers are less important than the trends we show through the simulation exercise. The Chinese LCOEs for parabolic trough plants and for tower plants are similar, where in other contexts, as we have seen in Section 3.1, tower plants have lower prices. This may partially explain why in China similar megawatt-amounts of parabolic trough plants and tower plants are in the pipeline.

Another difference between the CSP costs in China and in U.S. is that the lowest LCOE for a U.S. CSP tower plant is typically achieved with a SM of more than 2.5 and 12 hours of storage (Jorgenson et al. 2013). But for the simulated Chinese tower plant, there is very limited LCOE reduction after SM has reached 1.6-1.8 with 4-6 hours of storage. This result might be impacted 
by the input where the thermal energy storage costs for towers are higher than those for trough plants in China, and it is worth investigating with more-robust cost information.

\section{Analysis of System Operation Value of CSP in China}

To assess the value of CSP in reducing overall power system operation cost, we built a production cost model with coal, wind, solar PV, and CSP generators, and without transmission constraints. The methods for valuing CSP with thermal energy storage using production cost modeling is documented in Denholm et al. 2015. We built on the previous study by evaluating the CSP value within the operational context of the Chinese power system. This section describes the production cost model we built for the analysis, provides the basic setup of the test system, and analyzes the results.

\subsection{Production Cost Model}

We propose a two-stage unit-commitment strategy that resembles the Chinese power system operation: a weekly unit commitment (referred to as long-term unit commitment) and a daily economic dispatch. In the long-term unit commitment, the generators are scheduled for a period of seven days, which is the optimization horizon. The CSP plant is not considered in the longterm unit commitment, but wind and solar PV plants are included. The wind and solar PV forecast information used in the long-term unit commitment is based on the historical capacity factors of wind power and solar PV. Limited as it is, using historical wind generation as the forecast over this weekly step can give us a rough unit starts and shutdown schedule for large coal-fired generators that take a long time to start. After the model determines the generator schedules based on weekly unit commitment, it performs daily economic dispatch of all generators including the CSP plant. The daily economic dispatch updates the long-term unit commitment schedules using the updated wind, solar PV, and CSP output profiles on a daily basis. The main differences between the long-term unit commitment and the daily economic dispatch model are the optimization horizon and the commitment status of conventional generators.

The objective function of the model is to minimize the total cost of generation and the cost of unserved load. It could be expressed as:

$$
f_{o b j}=\sum_{t \in T} C_{G e n}(t)+\sum_{t \in T} C_{C S P}(t)+\sum_{t \in T} C_{L C}(t)
$$

where $C_{G e n}(t)$ is the generation cost of all other generators except CSP at time period $t, C_{C S P}(t)$ is the cost of CSP generation cost at $\mathrm{t}, C_{L C}(t)$ is the cost of unserved load at $t$, and $T$ is the total optimization period for the unit commit and economic dispatch problem, e.g., the 8,760 hours of a simulation year.

$C_{G e n}(t)$ includes unit startup cost, fixed operation cost, and variable operation and maintenance cost. Fuel cost and $\mathrm{CO}_{2}$ emission cost are included in the operation and maintenance cost.

$C_{C S P}(t)$ mainly includes the startup cost of the CSP generator and could be expressed as: 


$$
C_{C S P}(t)=\sum_{u_{N}^{c s p} \in U_{N}^{c s p}}\left(c_{s t a r t}^{c s p}\left(u_{N}^{c s p}\right) \cdot V_{\text {start }}^{c s p}\left(u_{N}^{c s p}, t\right)\right)
$$

where $U_{N}^{c s p}$ is the type of the CSP generator in the simulation, $u_{N}^{c s p}$ is a CSP unit, $c_{\text {start }}^{c s p}\left(u_{N}^{c s p}\right)$ is the startup cost of a CSP unit, and $V_{\text {start }}^{c s p}\left(u_{N}^{c s p}, t\right)$ is the number of unit starts. We omit the variable operation and maintenance costs of CSP in the dispatch model.

The cost of unserved energy $C_{L C}(t)$ is the system cost incurred by insufficient generation in the power system. Because transmission is not considered in the model, no unserved energy can be caused by transmission congestion. The cost of unserved energy can be expressed as:

$$
C_{L C}(t)=c_{\text {voll }} \cdot V_{\text {loadcurt }}(t)
$$

where $c_{v o l l}$ is the value of lost load, $V_{\text {loadcurt }}(t)$ is the amount of unserved energy or load curtailed.

The model considers four common power system operation constraints, such as unit start and ramping constraints. The primary constraint is the power balance constraint, expressed as:

$$
\sum_{u_{N} \in U_{N}} V_{g e n}\left(u_{N}, t\right)+\sum_{u_{N}^{c s p} \in U_{N}^{c s p}} V_{g e n}^{c s p}\left(u_{N}^{c s p}, t\right)+P_{\text {vre }}(t)-V_{\text {vrecurt }}(t)+V_{\text {loadcurt }}(t)=P_{\text {dem }}(t), \forall_{t}
$$

where $U_{N}$ is the conventional generation type, $u_{N}$ is the unit, $V_{g e n}\left(u_{N}, t\right)$ is the generation output of the conventional unit, $V_{g e n}^{c s p}\left(u_{N}^{c s p}, t\right)$ is the power output of CSP generation module at time period $t, P_{\text {vre }}(t)$ is the wind and solar PV generation at $t, V_{\text {vrecurt }}(t)$ is the variable renewable energy curtailment, including wind, solar PV, and CSP at t, $V_{\text {loadcurt }}(t)$ is the load curtailment or unserved energy at $t$, and $P_{d e m}(t)$ is the load at $t$.

The second constraint establishes the linkage between the CSP generation module and the CSP storage module. This constraint could be expressed as:

$$
\sum_{u_{N}^{c s p} \in U_{N}^{c s p}} V_{\text {storage_out }}^{c s p}\left(u_{N}^{c s p}, t\right)-\sum_{u_{N}^{c s p} \in U_{N}^{c s p}} V_{\text {start }}^{c s p}\left(u_{N}, t\right) \cdot S T_{\text {start }}^{c s p}\left(u_{N}^{c s p}, t\right)-\sum_{u_{N}^{c s p} \in U_{N}^{c s p}} V_{\text {gen }}^{c s p}\left(u_{N}^{c s p}, t\right)=0, \forall t
$$

where $V_{\text {storage_out }}^{c s p}\left(u_{N}^{c s p}, t\right)$ is the output power of the storage module, $V_{\text {start }}^{c s p}\left(u_{N}^{c s p}, t\right)$ is the number of starts of the CSP unit, $S T_{\text {start }}^{c s p}\left(u_{N}^{c s p}, t\right)$ is the power needed to start the CSP generation, and $V_{g e n}^{c s p}\left(u_{N}^{c s p}, t\right)$ is the power output of the CSP generation module. We do not include any part-load efficiency loss for the CSP generator in this model.

The third constraint is the CSP generation and storage constraint, which can be expressed as:

$$
\begin{aligned}
& V_{\text {storage_energy }}^{c s p}(t)=\operatorname{coeff}_{1}^{c s p} \cdot V_{\text {storage_energy }}^{c s p}(0)+V_{\text {storage_in }}^{c s p}(t)-\operatorname{coeff}_{2}^{c s p} \cdot V_{\text {storage_out }}^{c s p}(t), t=1 \\
& V_{\text {storage_energy }}^{c s p}(t)=\operatorname{coeff}_{1}^{c s p} \cdot V_{\text {storage }}^{c s p e r g y}(t-1)+V_{\text {storage }}^{c s p}(t)-\operatorname{coeff}_{2}^{c s p} \cdot V_{\text {storag }_{\text {out }}}^{\text {csp }}(t), t>1
\end{aligned}
$$


where $V_{\text {storage }}^{c s p}(t)$ is the stored energy of the CSP storage module at time period $t$, coef $f_{1}^{c s p}$ is the coefficient of efficiency loss from the CSP storage, $V_{\text {storage }}^{c s p}$ energy $^{(0)}$ is the initial energy of the CSP storage module, $V_{\text {storage }}^{c s p}(t)$ is the power input from the solar field into the CSP storage module as produced by SAM through the previous simulation, $V_{\text {storage_out }}^{c s p}\left(u_{N}^{c s p}, t\right)$ is the power output from the CSP storage module into the generation module, $\operatorname{coeff} f_{2}^{\operatorname{cs} p}$ is the coefficient of the efficiency loss from the CSP generation.

The fourth constraint is the maximum and minimum generation level constraint. This constraint establishes the operation boundaries of coal and CSP generators. The coal generators' constraint could be expressed as:

$$
\begin{gathered}
\sum_{u_{N} \in U_{N}}\left(V_{\text {gen }}\left(u_{N}, t\right)\right) \leq P_{\text {max }}\left(U_{N}\right) \cdot N\left(U_{N}\right), \forall t \\
\sum_{u_{N} \in U_{N}}\left(V_{\text {gen }}\left(u_{N}, t\right)\right) \geq P_{\text {min }}\left(U_{N}\right) \cdot N\left(U_{N}\right), \forall t \\
V_{\text {gen }}\left(u_{N}, t\right) \geq V_{\text {online }}\left(u_{N}, t\right) \cdot P_{\text {min }}\left(u_{N}\right), \forall t, u_{N} \\
V_{\text {gen }}\left(u_{N}, t\right) \leq V_{\text {online }}\left(u_{N}, t\right) \cdot P_{\text {max }}\left(u_{N}\right), \forall t, u_{N}
\end{gathered}
$$

where $U_{N}$ is the conventional generation type, $u_{N}$ is the unit, $N\left(U_{N}\right)$ is the number of units for each generation type, $V_{g e n}$ is the generation output, $V_{\text {online }}$ is the number of units operating at the given time, and $P_{\max }\left(u_{N}\right) 、 P_{\min }\left(u_{N}\right)$ is the maximum and minimum generation level of $u_{N}$. Because all coal units in each coal generation type are identical, this simplified constraint achieves the overall minimum generation and maximum generation boundaries without constraining every individual unit. The constraint for CSP generators is as follows:

$$
\begin{aligned}
& V_{\text {gen }}^{c s p}\left(u_{N}^{c s p}, t\right) \geq V_{\text {online }}^{c s p}\left(u_{N}^{c s p}, \mathrm{t}\right) \cdot P_{\min }^{c s p}\left(u_{N}^{c s p}\right), \forall t, u_{N}^{c s p} \\
& V_{\text {gen }}^{c s p}\left(u_{N}^{c s p}, t\right) \leq V_{\text {online }}^{c s p}\left(u_{N}^{c s p}, \mathrm{t}\right) \cdot P_{\max }^{c s p}\left(u_{N}^{c s p}\right), \forall t, u_{N}^{c s p}
\end{aligned}
$$

where $P_{\min }^{c s p}\left(u_{N}^{c s p}\right)$ is the technical minimum output level of the CSP generation module, and $P_{\max }^{c s p}\left(u_{N}^{c s p}\right)$ is the technical maximum output level of the CSP generation module. 


\subsection{Test System}

We built a one-node test system with a mix of coal, wind, solar PV, and CSP generation capacity (Figure 8). The purpose of our production cost modeling is to estimate the impact on system operation cost by different configurations of CSP, not to provide a specific dollar value for the CSP in a given system because that is depedent upon many regulatory and market factors. The generation composition of the test system is similar to that of the Northwest Grid, but without any hydro generation. Because the operation of hydro is often constrained by regulatory, agricultural, environmental and other non-power system factors, and is not the focus of our study, we omitted hydro for simplification. In the test system, wind accounts for $27.03 \%$ of installed capacity, compared with $18.85 \%$ in China's Northwest Grid in 2018; solar accounts for $13.51 \%$ of the test system capacity, compared with $16.47 \%$ in the Northwest Grid; and coal accounts for $58.11 \%$ of the test system capacity, compared with $56.35 \%$ in the Northwest Grid. We use more wind capacity than solar because of the projected faster growth of wind in the Northwest region under China's $13^{\text {th }}$ Five Year Plan.

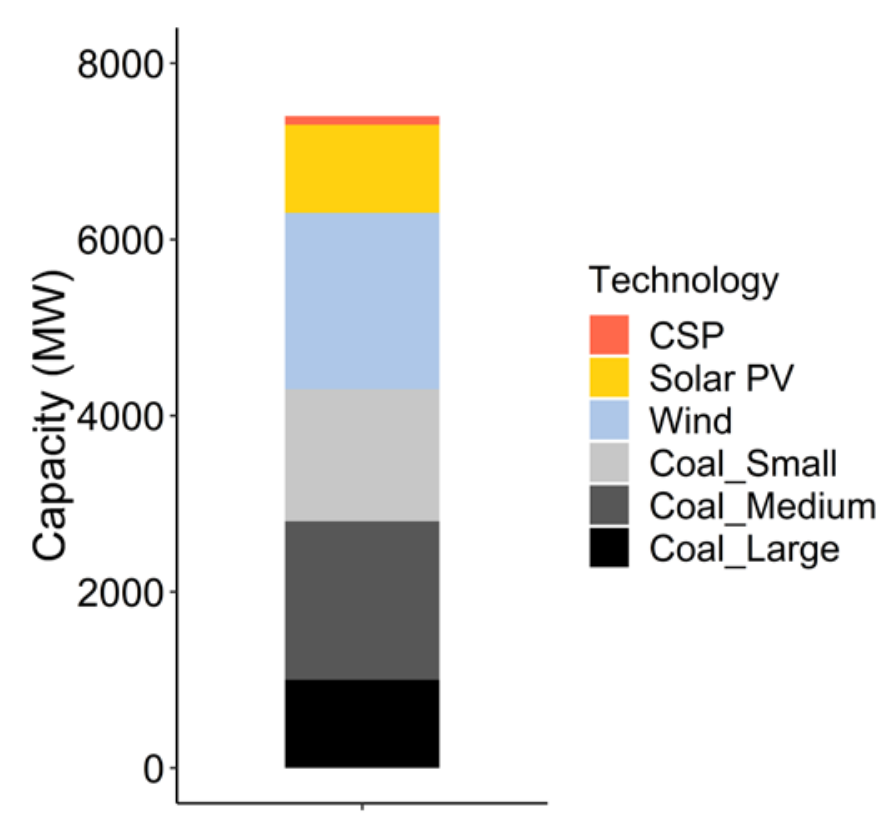

Figure 8. Installed capacity in the test system

The parameters we used to represent the coal generation units are summarized in Table 3. They represent typical coal plants in China's Northwest region. 
Table 3. Conventional (Coal) Generators in the Test System

\begin{tabular}{|l|r|r|r|}
\hline Nameplate Capacity (MW) & $\mathbf{1 , 0 0 0}$ & $\mathbf{6 0 0}$ & $\mathbf{3 0 0}$ \\
\hline Units & 1 & 3 & 5 \\
\hline Fixed fuel consumption (kg/hour) & 143,507 & 88,421 & $47,657.8$ \\
\hline Variable fuel consumption Band 1 (kg/MWh) & 246.4 & 263.2 & 281.5 \\
\hline Variable fuel consumption Band 2 (kg/MWh) & 252.8 & 265.0 & 286.0 \\
\hline Variable fuel consumption Band 3 (kg/MWh) & 259.3 & 266.9 & 290.5 \\
\hline Minimum stable level (\%) & 50.0 & 50.0 & 50.0 \\
\hline Ramp rate (\%/hour) & 2 & 2 & 2 \\
\hline Start time (hour) & 10 & 8 & 6 \\
\hline Startup cost (\$3) & 148,000 & 88,800 & 44,400 \\
\hline Minimum downtime (hour) & 5 & 4 & 4 \\
\hline Minimum uptime (hour) & 10 & 6 & 6 \\
\hline
\end{tabular}

We used a scaled-down version of a typical load profile of the Northwest China as the load for the test system, and we used typical wind and solar profiles of that region as the renewable output profiles. We added a 100-MW tower CSP to the test system with five different configurations (Table 4) that are estimated to be relatively cost-efficient from our previous LCOE analysis. The CSP unit is configured according to the properties in Table 5. We did not consider the effects of part loading or multiple starts on plant efficiency.

Table 4. CSP Generator Configurations in the Test System

\begin{tabular}{|l|c|c|}
\hline Case & Solar Multiple (SM) & Hours of Storage (H) \\
\hline Reference Case (Case 1) & 1.6 & 4 \\
\hline Case 2 & 1.6 & 6 \\
\hline Case 3 & 1.6 & 8 \\
\hline Case 4 & 1.8 & 6 \\
\hline Case 5 & 1.8 & 8 \\
\hline
\end{tabular}

${ }^{3}$ All costs in the model were converted to U.S. dollars (USD) using the average currency exchange rate in 2017 ( $\$ 1=$ RMB 6.7568). 
Table 5. CSP Generator Properties in the Test System

\begin{tabular}{|l|c|}
\hline Rated Capacity (MW) & $\mathbf{1 0 0}$ \\
\hline Units & 1 \\
\hline Startup power consumption (\% of Rated Capacity) & 20 \\
\hline Minimum stable level (\%) & 25 \\
\hline Ramp rate (\%) & 2 \\
\hline Start-up time (hour) & 1 \\
\hline Start-up cost (USD) & 14,800 \\
\hline
\end{tabular}

\subsection{Case Study Results}

The production cost modeling results show that in the Reference Case, wind accounts for $15.5 \%$ of the total generation, solar PV accounts for 8.4\%, and CSP accounts for 1\% (Figure 9, left panel). As the solar multiple expand from 1.6 to 1.8, we observe a significant increase of CSP generation and replacement of coal power generation, up to 68.6 gigawatt-hours $(\mathrm{GWh})$ of CSP generation and 64.3 GWh of coal generation reduction (Figure 9, right panel).
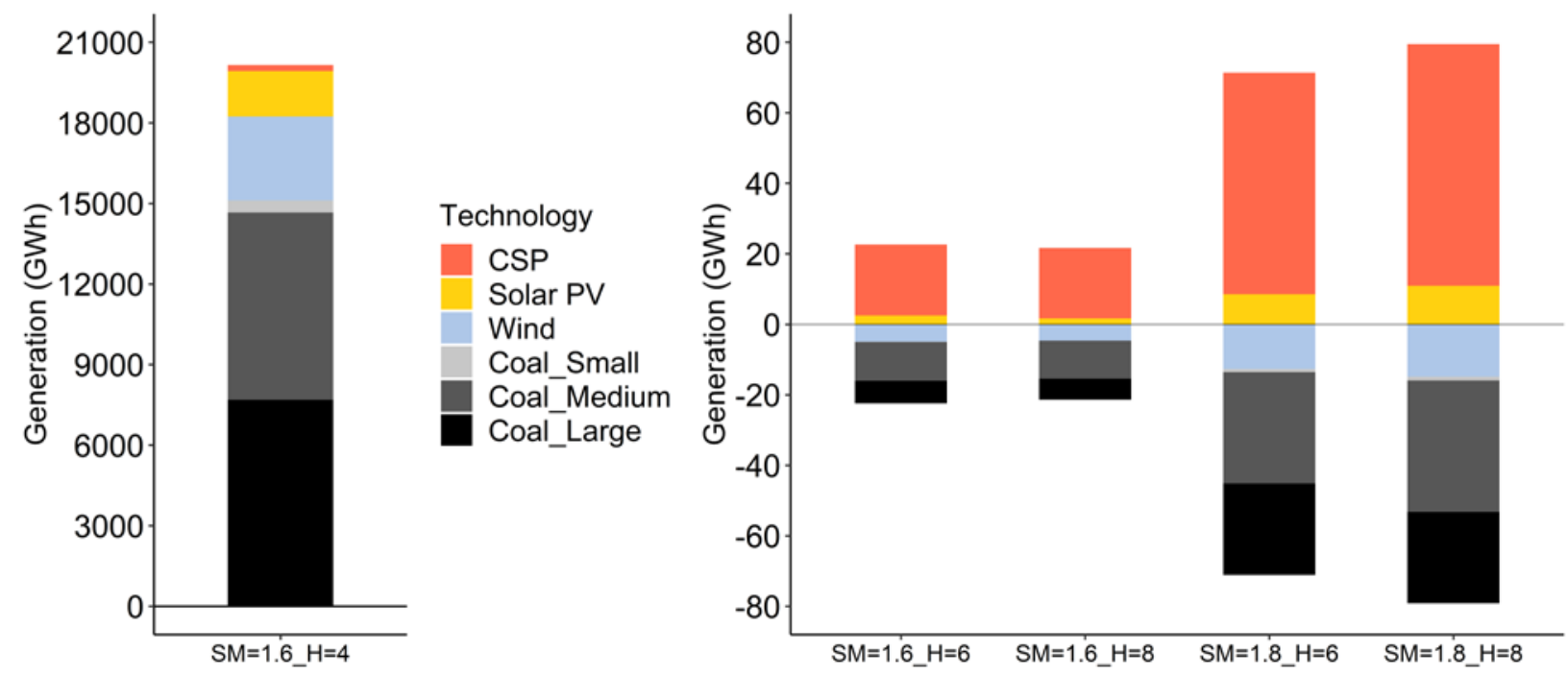

Figure 9. Generation stack of Reference Case ( $S M=1.6, H=4$, left) and Cases 2-5, generation difference from the Reference Case (right)

We analyzed the hourly operation of the CSP unit by focusing on the intra-day patterns of system operation. The highest renewable penetration occurs on May 2 for the test system (Figure 10). The instant wind and solar PV penetration reaches $63.5 \%$ on that day and causes 5,950-6,434 MWh of total curtailment (including wind, solar PV, and CSP), depending on the CSP configuration. Most of the curtailment occurs during midday and late at night. During the high renewable penetration periods, the coal generators back down to their minimum generation levels during the day and ramp up to serve the evening ramp after 7:00 p.m.. Figure 11 shows that the large coal plant drops to its minimum generation level of $50 \%$ in the hourly economic dispatch (solid line), compared to the long-term unit commitment (dotted line). The thermal 
storage of the CSP unit starts charging at 9:00 a.m., which helps reduce the midday curtailment, and it starts to discharge at 6:00 p.m. to contribute to the evening ramp, when solar PV production drops (Figure 12). The CSP unit is configured so that the power from the solar field passes through the thermal storage to the turbine generator, so there is concurrent charging and discharging.

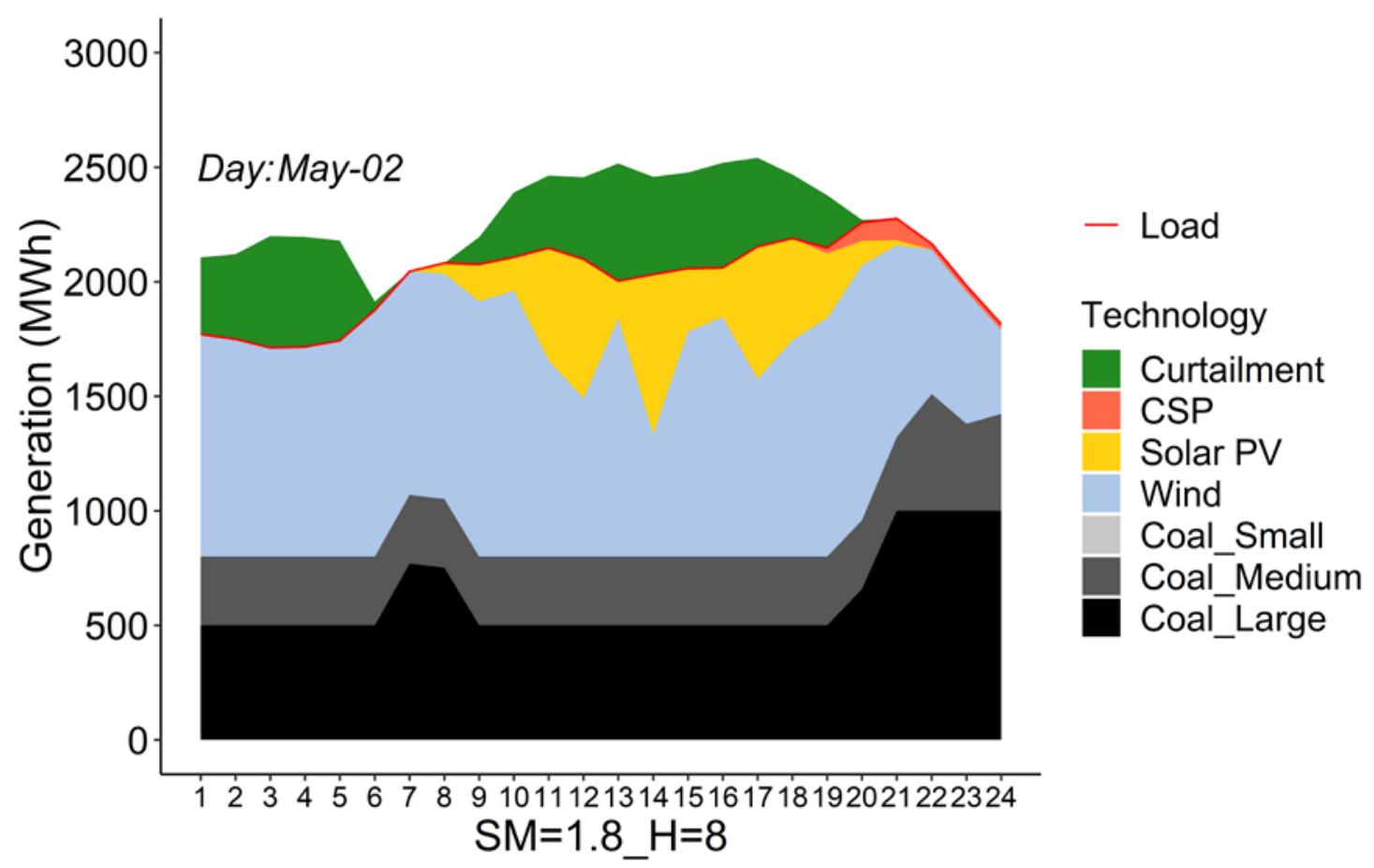

Figure 10. Dispatch for May 2 under Case $5(\mathrm{SM}=1.8, \mathrm{H}=8)$

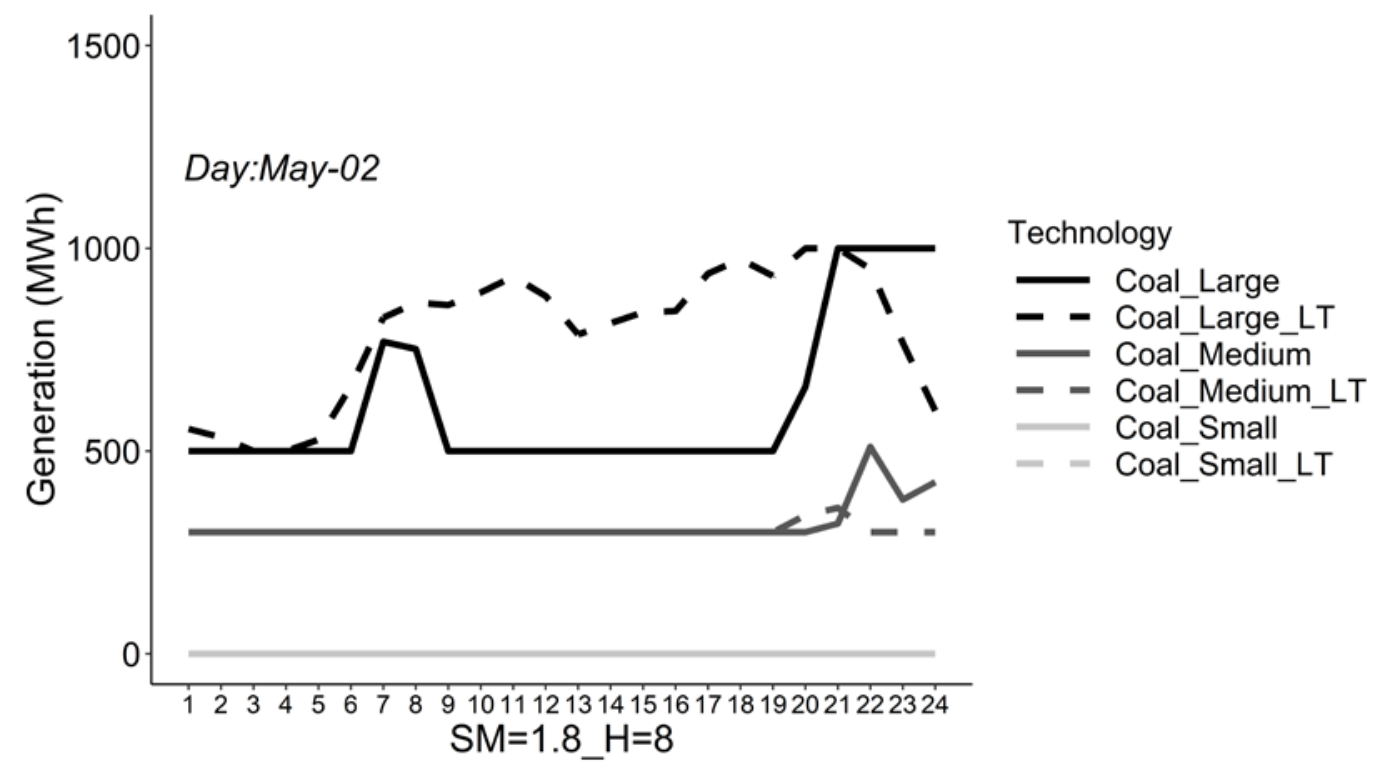

Figure 11. Coal long-term (LT) unit commitment and short-term economic dispatch under Case 3 $(\mathrm{SM}=1.6, \mathrm{H}=8)$ 


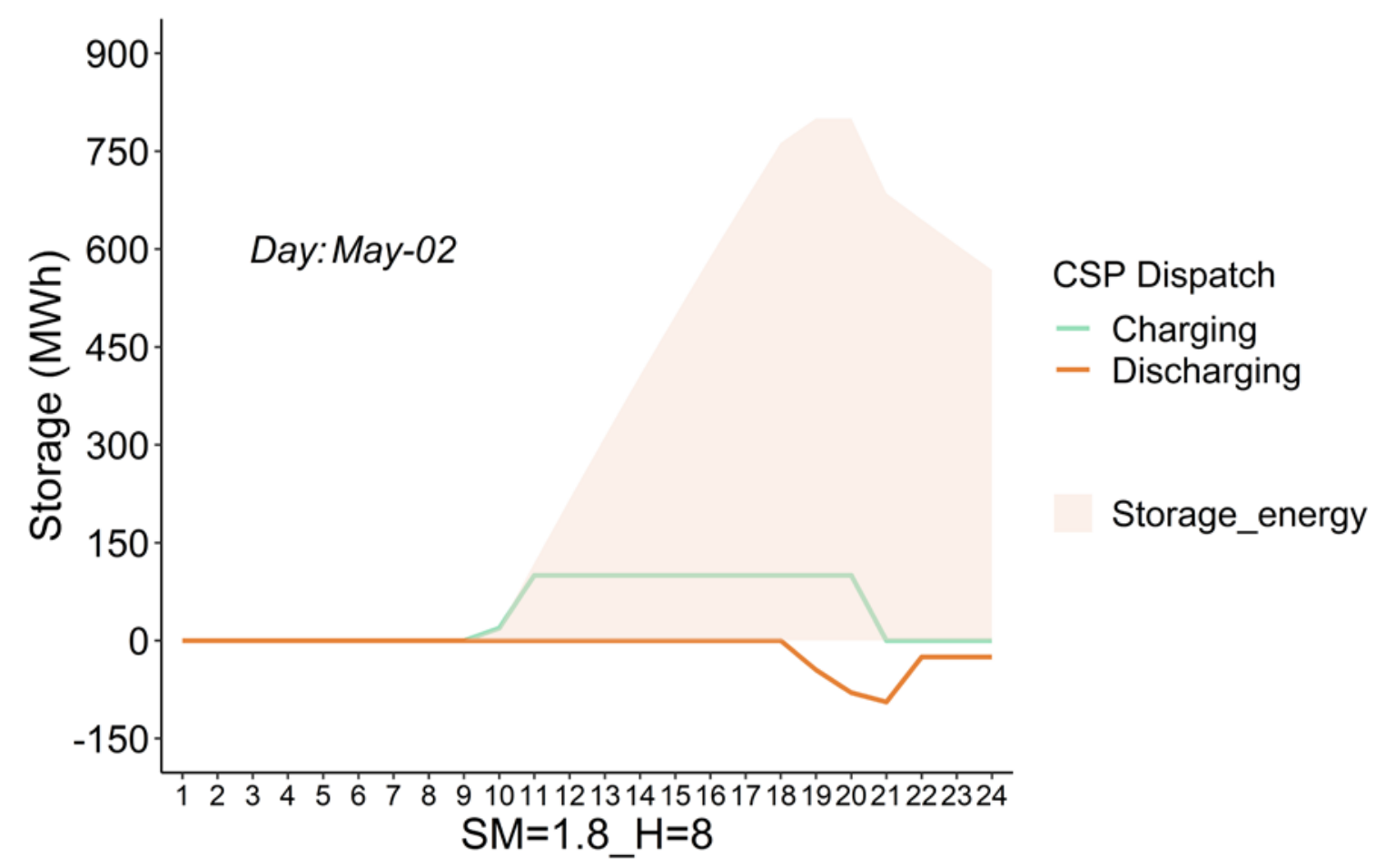

Figure 12. CSP thermal storage operation on May 2 under Case $5(S M=1.8, H=8)$

Increasing the CSP storage size reduces total renewable energy curtailment from wind, solar PV, and CSP. We calculated renewable energy curtailment as the available renewable output minus generation; however, in the real world, the allocation of curtailment may be different among these technologies. As Figure 13 shows, renewable energy curtailment in the test system is concentrated in the noon-to-afternoon period and after midnight. The thermal storage of CSP can shift generation from the noon-to-afternoon period to the evening (as shown in Figure 12), but it is not long enough to shift it to the ramping period of the next morning - that would require more than 12 hours of storage. As a result, longer storage hours (4-8 hours) lead to reduced curtailment in the afternoon, but larger solar multiples and longer storage hours lead to a slight increase of curtailment at nighttime (Figure 14). 


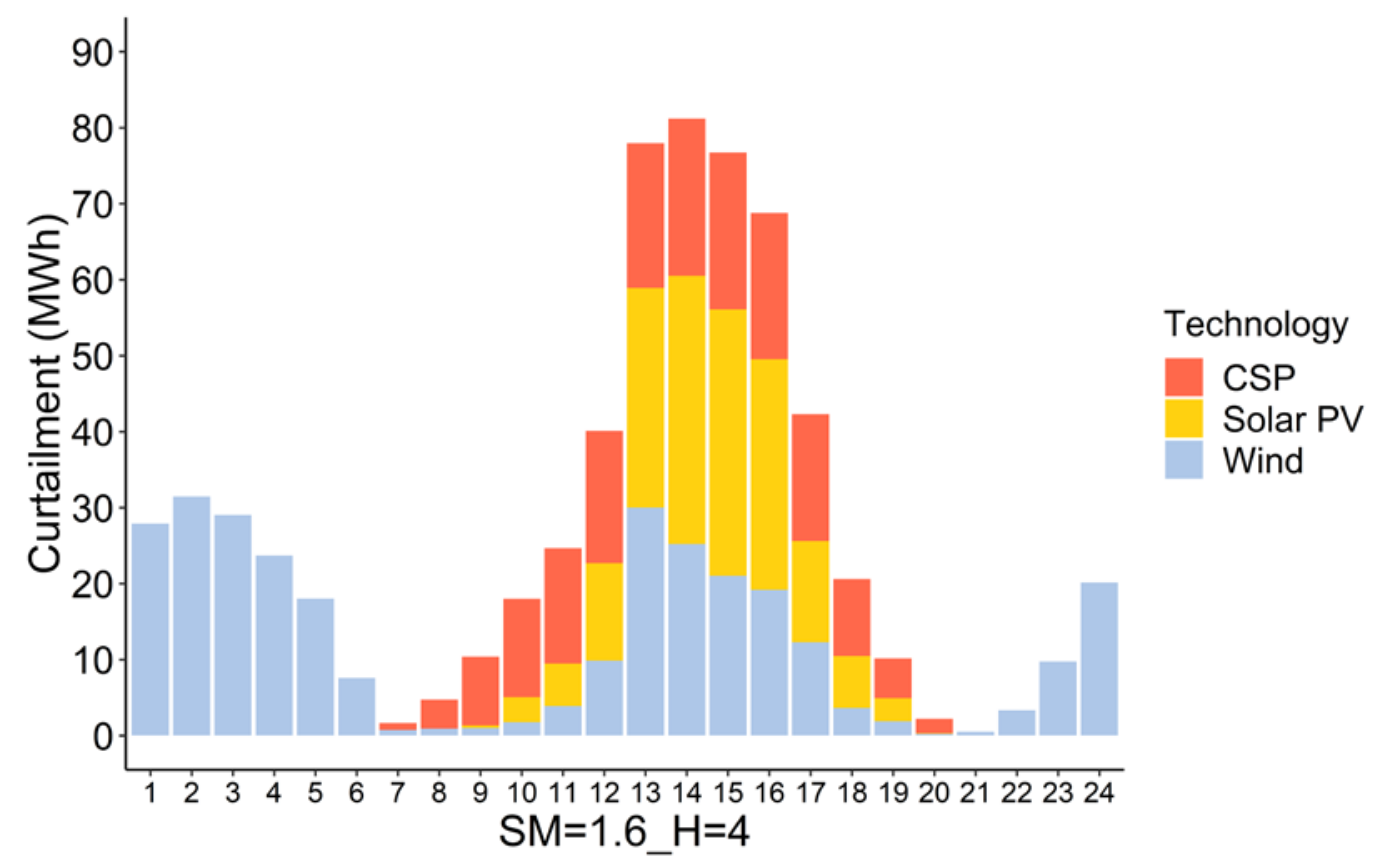

Figure 13. Annual curtailment averaged to the hour of the day for the Reference Case

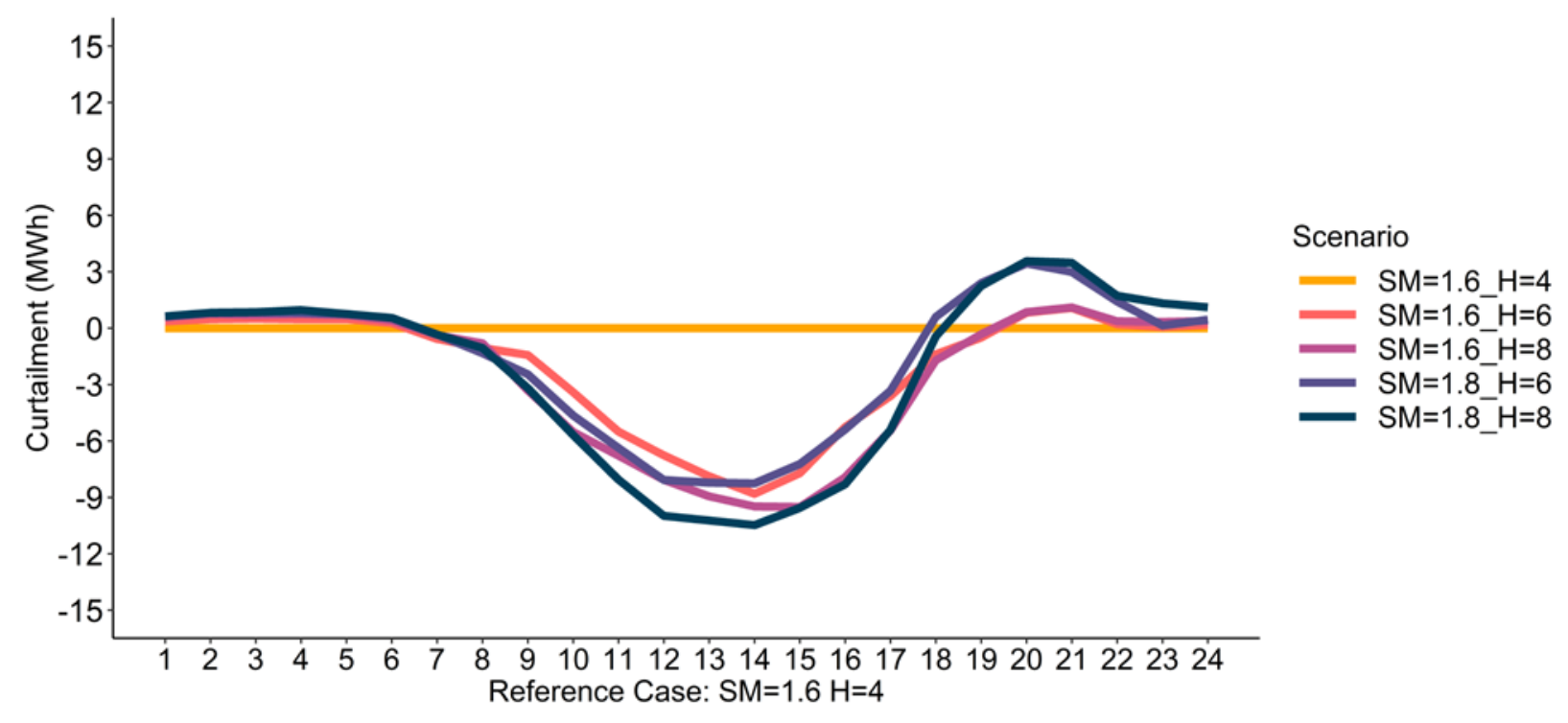

Figure 14. Difference in total curtailment from the Reference Case

Overall, even just $100 \mathrm{MW}$ of CSP can bring moderate savings on total system operation cost and reduced curtailment of renewables. As summarized in Table 6, changing from 4-hour storage to 8-hour storage for the CSP unit with a solar multiple of 1.6 can result in $\$ 1.26$ million $(0.39 \%)$ in annual cost savings. Larger storage reduces the CSP curtailment by $40.14 \%$, but it increases the wind and solar PV curtailment by $1.70 \%$, leading to a total reduction in overall renewable energy curtailment of $9.41 \%$. Greater solar multiples and storage duration (a SM of 1.8 and storage length of 8 hours) lead to higher cost savings of up to $\$ 2.19$ million $(0.69 \%)$ because of the replacement of coal generation, and an $8.40 \%$ reduction in total renewable energy curtailment. 
Table 6. Impact on Total System Operation Cost and Renewable Energy Curtailment

\begin{tabular}{|c|c|c|c|c|c|c|c|}
\hline SM & $\begin{array}{l}\text { Storage } \\
\text { Hours }\end{array}$ & $\begin{array}{l}\text { System } \\
\text { Operation Cost } \\
\text { (million USD) }\end{array}$ & $\begin{array}{l}\text { Cost Difference } \\
\text { from Reference } \\
\text { Case }\end{array}$ & $\begin{array}{l}\text { CSP } \\
\text { Curtailment } \\
\text { (MWh) }\end{array}$ & $\begin{array}{l}\text { CSP Curtailment } \\
\text { Difference from } \\
\text { Reference Case }\end{array}$ & $\begin{array}{l}\text { Wind and Solar } \\
\text { PV Curtailment } \\
\text { (MWh) }\end{array}$ & $\begin{array}{l}\text { Wind and Solar PV } \\
\text { Curtailment Difference } \\
\text { from Reference Case }\end{array}$ \\
\hline 1.6 & 4 & 318.21 & - & $63,136.88$ & - & $174,496.45$ & - \\
\hline 1.6 & 6 & 317.11 & $-0.34 \%$ & $42,863.43$ & $-32.11 \%$ & $176,887.16$ & $1.37 \%$ \\
\hline 1.6 & 8 & 316.95 & $-0.39 \%$ & $37,794.43$ & $-40.14 \%$ & $177,468.84$ & $1.70 \%$ \\
\hline 1.8 & 6 & 316.33 & $-0.59 \%$ & $44,494.61$ & $-29.53 \%$ & $178,610.83$ & $2.36 \%$ \\
\hline 1.8 & 8 & 316.02 & $-0.69 \%$ & $39,225.38$ & $-37.87 \%$ & $178,446.14$ & $2.26 \%$ \\
\hline
\end{tabular}




\section{Discussion and Conclusions}

With China's growing interest in CSP, understanding the Chinese policy context of CSP development and the cost and the value of CSP in the power system is increasingly important. A deep analysis of the cost and value of CSP in China would require building a nodal model of the Northwest Region with more accurate representations of the generation and transmission constraints in the region. Due to data limitations, we used a simplified version of the Northwest regional system for the analysis. Note that each of the provincial power systems of the Northwest provinces - Shaanxi, Gansu, Qinghai, Ningxia, and Xinjiang - is very different from one another, so the value of CSP can be different in each province within the region. In Qinghai province, the balancing area where many CSP facilities are or are proposed to be built, a $\pm 800 \mathrm{kV} \mathrm{DC}$ transmission line is being built between Qinghai and He'nan to transport renewable energy generation from Qinghai province to Central China. Such transmission development will likely drive a change in CSP values in the system, so future research may build upon our work by using more accurate data and more detailed power system representation.

Our study provided the initial data and methodology that can be used to analyze the cost and value of CSP in China. We showed that the LCOEs of both parabolic troughs and tower plants are around 15.0-15.8 U.S. cents/kWh in China under current conditions. This is slightly lower than China's CSP feed-in tariff in 2018 of 17.2 U.S. cents/kWh. We extended the previous research (Denholm et al. 2015) on CSP value estimation by making a production cost model that represents the Chinese power system operation context and applying it for the analysis of CSP. We demonstrated the impacts of CSP on various aspects of system operation. We showed that larger solar multiples and longer storage hours can contribute to savings in system operation costs and reductions of renewable energy curtailment. 


\section{References}

Blair, Nate, Nicholas Diorio, Janine Freeman, Paul Gilman, Steven Janzou, Ty Neises, and Michael Wagner. 2018. "System Advisor Model (SAM) General Description (Version 2017.9.5)." www.nrel.gov/publications.

Chen, Wenying, Hualin Li, and Zongxin Wu. 2010. "Western China Energy Development and West to East Energy Transfer: Application of the Western China Sustainable Energy Development Model." Energy Policy 38 (11): 7106-20. https://doi.org/10.1016/j.enpol.2010.07.029.

CRES. 2013. “中国光伏发展路线图 2050 [China Solar Photovotaic Development Roadmap 2050].” Beijing.

CSP Plaza. 2019. “国家发改委价格司就光热示范项目延期电价政策组织研讨.” 2019. http://www.cspplaza.com/article-15891-1.html.

Denholm, Paul, Jennie Jorgenson, Mackay Miller, Ella Zhou, and Caixia Wang. 2015. "Methods for Analyzing the Economic Value of Concentrating Solar Power with Thermal Energy Storage." Golden, CO. https://www.nrel.gov/docs/fy15osti/64256.pdf.

Gabbrielli, R., P. Castrataro, F. Del Medico, M. Di Palo, and B. Lenzo. 2014. "Levelized Cost of Heat for Linear Fresnel Concentrated Solar Systems." Energy Procedia 49 (January): 134049. https://doi.org/10.1016/J.EGYPRO.2014.03.143.

Hinkley, Jim, Bryan Curtin, Jenny Hayward, Alex $\$ \$$ Wonhas, Rod Boyd, Charles Grima, Amir Tadros, Ross Hall, Kevin Naicker, and Adeeb Mikhail. 2011. "Concentrating Solar Power Drivers and Opportunities for Cost-Competitive Electricity," no. March. www.csiro.au.

Hou, Hongjing, Yujin Yang, Yuqi Cui, Shutan Gao, and Yanjuan Pan. 2009. “Assessment of Concentrating Solar Power Prospect in China." Undefined. https://www.semanticscholar.org/paper/Assessment-of-concentrating-solar-power-prospectin-Hou-Yang/40760cc21c776aadd456c4473c9fdff15680c2e2.

IEA. 2010. "Technology Roadmap - Concentrating Solar Power." https://www.iea.org/publications/freepublications/publication/csp_roadmap.pdf.

International Renewable Energy Agency (IRENA). 2012. Renewable Energy Technologies Cost Analysis Series: Concentrating Solar Power, issued 2012. https://doi.org/10.1016/B978-008-087872-0.00319-X.

Jorgenson, Jennie, Paul Denholm, Mark Mehos, and Craig Turchi. 2013. "Estimating the Performance and Economic Value of Multiple Concentrating Solar Power Technologies in a Production Cost Model," no. December. http://www.nrel.gov/docs/fy14osti/58645.pdf.

Kincaid, Nicholas, Greg Mungas, Nicholas Kramer, Michael Wagner, and Guangdong Zhu. 2018. "An Optical Performance Comparison of Three Concentrating Solar Power Collector 
Designs in Linear Fresnel, Parabolic Trough, and Central Receiver." Applied Energy 231 (December): 1109-21. https://doi.org/10.1016/J.APENERGY.2018.09.153.

Li, Yuqiang, Shengming Liao, Zhenghua Rao, and Gang Liu. 2014. "A Dynamic Assessment Based Feasibility Study of Concentrating Solar Power in China." Renewable Energy 69: 34-42. https://doi.org/10.1016/j.renene.2014.03.024.

Lilliestam, Johan, Touria Barradi, Natalia Caldés, Marta Gomez, Susanne Hanger, Jürgen Kern, Nadejda Komendantova, et al. 2018. "Policies to Keep and Expand the Option of Concentrating Solar Power for Dispatchable Renewable Electricity." Energy Policy 116 (May): 193-97. https://doi.org/10.1016/J.ENPOL.2018.02.014.

Madaeni, S.H. Seyed Hossein, Ramteen Sioshansi, and Paul Denholm. 2013. "Estimating the Capacity Value of Concentrating Solar Power Plants With Thermal Energy Storage: A Case Study of the Southwestern United States.” IEEE Transactions on Power Systems 28 (2): 1205-15. https://doi.org/10.1109/TPWRS.2012.2207410.

Parrado, C., A. Girard, F. Simon, and E. Fuentealba. 2016. "2050 LCOE (Levelized Cost of Energy) Projection for a Hybrid PV (Photovoltaic)-CSP (Concentrated Solar Power) Plant in the Atacama Desert, Chile." Energy 94 (January): 422-30. https://doi.org/10.1016/J.ENERGY.2015.11.015.

Pierce, Warrick, Paul Gauché, Theodor von Backström, Alan C. Brent, and Amir Tadros. 2013. "A Comparison of Solar Aided Power Generation (SAPG) and Stand-Alone Concentrating Solar Power (CSP): A South African Case Study." Applied Thermal Engineering 61 (2): 657-62. https://doi.org/10.1016/J.APPLTHERMALENG.2013.08.014.

Qiu, Yu, Ya-Ling He, Ze-Dong Cheng, and Kun Wang. 2015. "Study on Optical and Thermal Performance of a Linear Fresnel Solar Reflector Using Molten Salt as HTF with MCRT and FVM Methods." Applied Energy 146 (May): 162-73. https://doi.org/10.1016/J.APENERGY.2015.01.135.

Sargent \& Lundy. 2003. "Assessment of Parabolic Trough and Power Tower Solar Technology Cost and Performance Forecasts." Report No. NREL/SR-550-34440, no. October: 47. https://doi.org/NREL/SR-550-34440.

Turchi, Craig, Mark Mehos, Clifford K Ho, and Gregory J Kolb. 2010. "Current and Future Costs for Parabolic Trough and Power Tower Systems in the US Market Preprint." 16th SolarPACES Conference, Perpignan, France. https://www.nrel.gov/analysis/sam/.

Ummel, Kevin. 2010. “Concentrating Solar Power in China and India: A Spatial Analysis of Technical Potential and the Cost of Deployment." Ssrn, no. July 2010. https://doi.org/10.2139/ssrn.1694129.

Wang, Jun, Song Yang, Chuan Jiang, Yaoming Zhang, and Peter D. Lund. 2017. "Status and Future Strategies for Concentrating Solar Power in China." Energy Science \& Engineering 5 (2): 100-109. https://doi.org/10.1002/ese3.154. 
Wang, Zhifeng. 2010. "Prospectives for China's Solar Thermal Power Technology Development." Energy 35 (11): 4417-20. https://doi.org/10.1016/j.energy.2009.04.004.

Zhao, Zhen-Yu Yu, Yu-Long Long Chen, and John Douglas Thomson. 2017. "Levelized Cost of Energy Modeling for Concentrated Solar Power Projects: A China Study." Energy 120 (February): 117-27. https://doi.org/10.1016/j.energy.2016.12.122.

中华人民共和国国务院 State Council of the People’s Republic of China. 2012. “国务院关于印 发工业转型升级规划（2011-2015年) 的通知[Notice of the State Council on the Industrial Transformation and Upgrading Plan (2011-2015)]." http://www.gov.cn/zwgk/2012-01/18/content_2047619.htm.

中华人民共和国国家发展和改革委员会NDRC. 2017. “战略性新兴产业重点产品和服务指 导目录（2016版）2017年第1号公告[Strategic Emerging Industry Key Products and Services Guidance Catalogue (2016 Edition) 2017 No. 1 Announcement].” http://www.ndrc.gov.cn/gzdt/201702/t20170204_837246.html.

中华人民共和国能源局NEA. 2015. “国家能源局关于组织太阳能热发电示范项目建设的通 知[ Notice of the National Energy Administration on the Organization of Solar Thermal Power Generation Demonstration Projects]." http://zfxxgk.nea.gov.cn/auto87/201509/t20150930_1968.htm.

—. 2016. “太阳能发展‘十三五”规划[13th Five-Year Solar Plan ].” http://zfxxgk.nea.gov.cn/auto87/201612/t20161216_2358.htm.

中国科学院 Chinese Academy of Sciences. 2009. “中国太阳能集热发电的可行性及政策研究 报告[China Solar Thermal Power Generation Feasibility and Policy Research Report].” http://www.efchina.org/Attachments/Report/reports-efchina-20110124-4-zh/中国太阳能集 热发电的可行性及政策研究报告.pd.

国家税务总局 State Administration of Taxation. 2018. “关于调整增值税税率的通知[ Notice on Adjusting the VAT Rate].”

http://www.chinatax.gov.cn/n810341/n810755/c3377945/content.html. 


\section{Appendix A. Literature Surveyed for LCOEs of Current and Simulated CSP Projects}

This appendix lists our surveyed literature for LCOEs of current and simulated CSP projects. Before each reference, in bold text, we indicate the:

- Technology:

○ $\mathrm{D}=$ dish Stirling

$\circ \quad \mathrm{L}=$ linear Fresnel

○ $\mathrm{P}=$ parabolic trough

○ $\mathrm{T}=$ power tower.

- Country

- Reference number

D-China(1): Li, Yuqiang, Shengming Liao, Zhenghua Rao, and Gang Liu. 2014. "A Dynamic Assessment Based Feasibility Study of Concentrating Solar Power in China." Renewable Energy 69: 34-42. https://doi.org/10.1016/j.renene.2014.03.024.

D-China(2): Zhu, Zhao, Da Zhang, Peggy Mischke, and Xiliang Zhang. 2015. "Electricity Generation Costs of Concentrated Solar Power Technologies in China Based on Operational Plants.” Energy 89: 65-74. https://doi.org/10.1016/j.energy.2015.07.034.

D-India: Beerbaum, S, and G Weinrebe. 2000. "Solar Thermal Power Generation in India: A Techno-Economic Analysis." Renewable Energy 21 (2): 153-74. https://doi.org/10.1016/S0960-1481(00)00006-9.

D-Spain: Pitz-Paal, Robert, Jürgen Dersch, and Barbara Milow. 2005. "European Concentrated Solar Thermal Road-Mapping.” Concrete. https://doi.org/10.1049/ess:20030508.

D-Thailand: Janjai, S., J. Laksanaboonsong, and T. Seesaard. 2011. "Potential Application of Concentrating Solar Power Systems for the Generation of Electricity in Thailand." Applied Energy 88 (12): 4960-67. https://doi.org/10.1016/j.apenergy.2011.06.044.

D-U.S.: Abakken, J. 2006. "Power Technologies Energy Data Book - Fourth Edition."NREL/TP-620-39728 . https://doi.org/10.2172/891585.

L-Spain(1): Desideri, Umberto, and Pietro Elia Campana. 2014. "Analysis and Comparison between a Concentrating Solar and a Photovoltaic Power Plant." Applied Energy 113: 422-33. https://doi.org/10.1016/j.apenergy.2013.07.046.

L-Spain(2): Pitz-Paal, Robert, Jürgen Dersch, and Barbara Milow. 2005. "European Concentrated Solar Thermal Road-Mapping." Concrete. https://doi.org/10.1049/ess:20030508. 
L-U.S.(1): Morin, Gabriel, Jürgen Dersch, Werner Platzer, Markus Eck, and Andreas Häberle. 2012. "Comparison of Linear Fresnel and Parabolic Trough Collector Power Plants." Solar Energy 86 (1): 1-12. https://doi.org/10.1016/j.solener.2011.06.020.

L-U.S.(2): Desideri, Umberto, and Pietro Elia Campana. 2014. "Analysis and Comparison between a Concentrating Solar and a Photovoltaic Power Plant." Applied Energy 113: 422-33. https://doi.org/10.1016/j.apenergy.2013.07.046.

P-Algeria(1): Boukelia, T. E., M. S. Mecibah, B. N. Kumar, and K. S. Reddy. 2015. "Investigation of Solar Parabolic Trough Power Plants with and without Integrated TES (Thermal Energy Storage) and FBS (Fuel Backup System) Using Thermic Oil and Solar Salt." Energy 88: 292-303. https://doi.org/10.1016/j.energy.2015.05.038.

P-Algeria(2): Boukelia, T E, M S Mecibah, B N Kumar, and K S Reddy. 2015. "Optimization, Selection and Feasibility Study of Solar Parabolic Trough Power Plants for Algerian Conditions." Energy Conversion and Management 101 (September): 450-59. https://doi.org/10.1016/J.ENCONMAN.2015.05.067.

P-Algeria(3): Viebahn, Peter, Yolanda Lechon, and Franz Trieb. 2011. "The Potential Role of Concentrated Solar Power (CSP) in Africa and Europe: A Dynamic Assessment of Technology Development, Cost Development and Life Cycle Inventories until 2050." Energy Policy 39 (8): 4420-30. https://doi.org/10.1016/j.enpol.2010.09.026.

P-Australia: Hinkley, Jim, Bryan Curtin, Jenny Hayward, Alex Wonhas, Rod Boyd, Charles Grima, Amir Tadros, Ross Hall, Kevin Naicker, and Adeeb Mikhail. 2011. "Concentrating Solar Power: Drivers and Opportunities for Cost-Competitive Electricity.” Virtoria:CSIRO. https://doi.org/10.4225/08/584d96820e27d.

P-China(1): Li, Yuqiang, Shengming Liao, Zhenghua Rao, and Gang Liu. 2014. "A Dynamic Assessment Based Feasibility Study of Concentrating Solar Power in China." Renewable Energy 69: 34-42. https://doi.org/10.1016/j.renene.2014.03.024.

P-China(2): Zhu, Zhao, Da Zhang, Peggy Mischke, and Xiliang Zhang. 2015. "Electricity Generation Costs of Concentrated Solar Power Technologies in China Based on Operational Plants.” Energy 89: 65-74. https://doi.org/10.1016/j.energy.2015.07.034.

P-China(3): Zhao, Zhen Yu, Yu Long Chen, and John Douglas Thomson. 2017. "Levelized Cost of Energy Modeling for Concentrated Solar Power Projects: A China Study." Energy 120: 11727. https://doi.org/10.1016/j.energy.2016.12.122.

P-Egypt: Desideri, Umberto, and Pietro Elia Campana. 2014. "Analysis and Comparison between a Concentrating Solar and a Photovoltaic Power Plant." Applied Energy 113: 422-33. https://doi.org/10.1016/j.apenergy.2013.07.046.

P-France: Spelling, James, Daniel Favrat, Andrew Martin, and Germain Augsburger. 2012. "Thermoeconomic Optimization of a Combined-Cycle Solar Tower Power Plant." Energy 41 (1): 113-20. https://doi.org/10.1016/j.energy.2011.03.073. 
P-India(1): Purohit, Ishan, and Pallav Purohit. 2010. "Techno-Economic Evaluation of Concentrating Solar Power Generation in India.” Energy Policy 38 (6): 3015-29.

https://doi.org/10.1016/j.enpol.2010.01.041.

P-India(2): Beerbaum, S, and G Weinrebe. 2000. "Solar Thermal Power Generation in India: A Techno-Economic Analysis." Renewable Energy 21 (2): 153-74. https://doi.org/10.1016/S0960-1481(00)00006-9.

P-Italy(1): Desideri, Umberto, and Pietro Elia Campana. 2014. "Analysis and Comparison between a Concentrating Solar and a Photovoltaic Power Plant." Applied Energy 113: 422-33. https://doi.org/10.1016/j.apenergy.2013.07.046.

P-Italy(2): Astolfi, Marco, Luca Xodo, Matteo C. Romano, and Ennio Macchi. 2011. "Technical and Economical Analysis of a Solar-Geothermal Hybrid Plant Based on an Organic Rankine Cycle." Geothermics 40 (1): 58-68. https://doi.org/10.1016/j.geothermics.2010.09.009.

P-Spain(1): Rovira, Antonio, Rubén Barbero, María José Montes, Rubén Abbas, and Fernando Varela. 2016. "Analysis and Comparison of Integrated Solar Combined Cycles Using Parabolic Troughs and Linear Fresnel Reflectors as Concentrating Systems." Applied Energy 162: 9901000. https://doi.org/10.1016/j.apenergy.2015.11.001.

P-Spain(2): Montes, M. J., A. Rovira, M. Muñoz, and J. M. Martínez-Val. 2011. "Performance Analysis of an Integrated Solar Combined Cycle Using Direct Steam Generation in Parabolic Trough Collectors." Applied Energy 88 (9): 3228-38. https://doi.org/10.1016/j.apenergy.2011.03.038.

P-Spain(3): Lilliestam, Johan, Jeffrey M. Bielicki, and Anthony G. Patt. 2012. "Comparing Carbon Capture and Storage (CCS) with Concentrating Solar Power (CSP): Potentials, Costs, Risks, and Barriers.” Energy Policy 47: 447-55. https://doi.org/10.1016/j.enpol.2012.05.020.

P-Spain(4): Pitz-Paal, Robert, Jürgen Dersch, and Barbara Milow. 2005. "European Concentrated Solar Thermal Road-Mapping." Concrete. https://doi.org/10.1049/ess:20030508.

P-Spain(5): Viebahn, Peter, Yolanda Lechon, and Franz Trieb. 2011. "The Potential Role of Concentrated Solar Power (CSP) in Africa and Europe: A Dynamic Assessment of Technology Development, Cost Development and Life Cycle Inventories until 2050." Energy Policy 39 (8): 4420-30. https://doi.org/10.1016/j.enpol.2010.09.026.

P-Thailand: Janjai, S., J. Laksanaboonsong, and T. Seesaard. 2011. "Potential Application of Concentrating Solar Power Systems for the Generation of Electricity in Thailand." Applied Energy 88 (12): 4960-67. https://doi.org/10.1016/j.apenergy.2011.06.044.

P-U.S.(1): Morin, Gabriel, Jürgen Dersch, Werner Platzer, Markus Eck, and Andreas Häberle. 2012. "Comparison of Linear Fresnel and Parabolic Trough Collector Power Plants." Solar Energy 86 (1): 1-12. https://doi.org/10.1016/j.solener.2011.06.020. 
P-U.S.(2): Rovira, Antonio, Rubén Barbero, María José Montes, Rubén Abbas, and Fernando Varela. 2016. "Analysis and Comparison of Integrated Solar Combined Cycles Using Parabolic Troughs and Linear Fresnel Reflectors as Concentrating Systems.” Applied Energy 162: 9901000. https://doi.org/10.1016/j.apenergy.2015.11.001.

P-U.S.(3): Montes, M. J., A. Rovira, M. Muñoz, and J. M. Martínez-Val. 2011. "Performance Analysis of an Integrated Solar Combined Cycle Using Direct Steam Generation in Parabolic Trough Collectors." Applied Energy 88 (9): 3228-38. https://doi.org/10.1016/j.apenergy.2011.03.038.

P-U.S.(4): Wagner, Sharon J., and Edward S. Rubin. 2014. "Economic Implications of Thermal Energy Storage for Concentrated Solar Thermal Power." Renewable Energy 61: 81-95. https://doi.org/10.1016/j.renene.2012.08.013.

P-U.S.(5): Lilliestam, Johan, Jeffrey M. Bielicki, and Anthony G. Patt. 2012. "Comparing Carbon Capture and Storage (CCS) with Concentrating Solar Power (CSP): Potentials, Costs, Risks, and Barriers." Energy Policy 47: 447-55. https://doi.org/10.1016/i.enpol.2012.05.020.

P-U.S.(6): Sargent \& Lundy. 2003. "Assessment of Parabolic Trough and Power Tower Solar Technology Cost and Performance Forecasts.” NREL/SR-550-34440. https://doi.org/10.2172/15005520.

P-U.S.(7): Astolfi, Marco, Luca Xodo, Matteo C. Romano, and Ennio Macchi. 2011. “Technical and Economical Analysis of a Solar-Geothermal Hybrid Plant Based on an Organic Rankine Cycle." Geothermics 40 (1): 58-68. https://doi.org/10.1016/j.geothermics.2010.09.009.

P-U.S.(8): Turchi, C. 2010. "Parabolic Trough Reference Plant for Cost Modeling with the Solar Advisor Model (SAM).” https://doi.org/10.2172/983729.

P-U.S.(9): Turchi, Craig, Mark Mehos, Clifford K Ho, and Gregory J Kolb. 2010. "Current and Future Costs for Parabolic Trough and Power Tower Systems in the US Market." NREL/CP5500-49303. https://www.osti.gov/servlets/purl/991556.

P-U.S.(10): Aabakken, J. 2006. "Power Technologies Energy Data Book-Fourth Edition" NREL/TP-620-39728 . https://doi.org/10.2172/891585.

P-Worldwide(1): Hernández-Moro, J., and J. M. Martínez-Duart. 2013. "Analytical Model for Solar PV and CSP Electricity Costs: Present LCOE Values and Their Future Evolution." Renewable and Sustainable Energy Reviews 20: 119-32. https://doi.org/10.1016/j.rser.2012.11.082.

P-Worldwide(2): Zhang, H.L, J Baeyens, J Degreve, and G Caceres. 2013. "Concentrated Solar Power Plants: Review and Design Methodology." Renewable and Sustainable Energy Reviews 22: 466-81. https://doi.org/10.1016/j.rser.2013.01.032.

P-Worldwide(3): Sovacool, Benjamin K. 2008. "Renewable Energy: Economically Sound, Politically Difficult." The Electricity Journal. 
P-Worldwide(4): International Renewable Energy Agency (IRENA). 2012. Renewable Energy Technologies Cost Analysis Series: Concentrating Solar Power. https://doi.org/10.1016/B978-008-087872-0.00319-X.

P-Worldwide(5): International Renewable Energy Agency (IRENA). 2018. "Renewable Power Generation Costs in 2017."Abu Dhabi. https:/www.irena.org//media/Files/IRENA/Agency/Publication/2018/Jan/IRENA_2017_Power_Costs_2018.pdf

T-Australia: Hinkley, Jim, Bryan Curtin, Jenny Hayward, Alex Wonhas, Rod Boyd, Charles Grima, Amir Tadros, Ross Hall, Kevin Naicker, and Adeeb Mikhail. 2011. "Concentrating Solar Power: Drivers and Opportunities for Cost-Competitive Electricity." Virtoria:CSIRO. https://doi.org/10.4225/08/584d96820e27d.

T-China(1): Li, Yuqiang, Shengming Liao, Zhenghua Rao, and Gang Liu. 2014. "A Dynamic Assessment Based Feasibility Study of Concentrating Solar Power in China." Renewable Energy 69: 34-42. https://doi.org/10.1016/j.renene.2014.03.024.

T-China(2): Zhu, Zhao, Da Zhang, Peggy Mischke, and Xiliang Zhang. 2015. "Electricity Generation Costs of Concentrated Solar Power Technologies in China Based on Operational Plants." Energy 89: 65-74. https://doi.org/10.1016/j.energy.2015.07.034.

T-India(1): Purohit, Ishan, and Pallav Purohit. 2010. "Techno-Economic Evaluation of Concentrating Solar Power Generation in India.” Energy Policy 38 (6): 3015-29.

https://doi.org/10.1016/j.enpol.2010.01.041.

T-India(2): Beerbaum, S, and G Weinrebe. 2000. "Solar Thermal Power Generation in India: A Techno-Economic Analysis." Renewable Energy 21 (2): 153-74. https://doi.org/10.1016/S0960-1481(00)00006-9.

T-Spain(1): Schwarzbözl, Peter, Reiner Buck, Chemi Sugarmen, Arik Ring, Ma Jesús Marcos Crespo, Peter Altwegg, and Juan Enrile. 2006. "Solar Gas Turbine Systems: Design, Cost and Perspectives." Solar Energy 80 (10): 1231-40. https://doi.org/10.1016/j.solener.2005.09.007.

T-Spain(2): Lilliestam, Johan, Jeffrey M. Bielicki, and Anthony G. Patt. 2012. "Comparing Carbon Capture and Storage (CCS) with Concentrating Solar Power (CSP): Potentials, Costs, Risks, and Barriers.” Energy Policy 47: 447-55. https://doi.org/10.1016/i.enpol.2012.05.020.

T-Spain(3): Pitz-Paal, Robert, Jürgen Dersch, and Barbara Milow. 2005. "European Concentrated Solar Thermal Road-Mapping." Concrete. https://doi.org/10.1049/ess:20030508.

T-Thailand: Janjai, S., J. Laksanaboonsong, and T. Seesaard. 2011. "Potential Application of Concentrating Solar Power Systems for the Generation of Electricity in Thailand." Applied Energy 88 (12): 4960-67. https://doi.org/10.1016/j.apenergy.2011.06.044.

T-U.S.(1): Schwarzbözl, Peter, Reiner Buck, Chemi Sugarmen, Arik Ring, Ma Jesús Marcos Crespo, Peter Altwegg, and Juan Enrile. 2006. "Solar Gas Turbine Systems: Design, Cost and Perspectives." Solar Energy 80 (10): 1231-40. https://doi.org/10.1016/j.solener.2005.09.007. 
T-U.S.(2): Sargent \& Lundy. 2003. "Assessment of Parabolic Trough and Power Tower Solar Technology Cost and Performance Forecasts.” NREL/SR-550-34440. https://doi.org/10.2172/15005520.

T-U.S.(3): Jorgenson, Jennie, Paul Denholm, Mark Mehos, and Craig Turchi. 2013. "Estimating the Performance and Economic Value of Multiple Concentrating Solar Power Technologies in a Production Cost Model.”. NREL/TP-6A20-58645. https://doi.org/10.2172/1260920.

T-U.S.(4): Mancini, Thomas R., Jesse A. Gary, Gregory J. Kolb, and Clifford Kuofei Ho. 2011. "Power Tower Technology Roadmap and Cost Reduction Plan." SAND2011-2419. https://doi.org/10.2172/1011644.

T-U.S.(5): Turchi, Craig, Mark Mehos, Clifford K Ho, and Gregory J Kolb. 2010. "Current and Future Costs for Parabolic Trough and Power Tower Systems in the US Market." NREL/CP5500-49303. https://www.osti.gov/servlets/purl/991556.

T-U.S.(6): Aabakken, J. 2006. "Power Technologies Energy Data Book - Fourth Edition.”NREL/TP-620-39728 . https://doi.org/10.2172/891585

T-Worldwide(1): Zhang, H.L, J Baeyens, J Degreve, and G Caceres. 2013. "Concentrated Solar Power Plants: Review and Design Methodology." Renewable and Sustainable Energy Reviews 22: 466-81. https://doi.org/10.1016/j.rser.2013.01.032.

T-Worldwide(2): International Renewable Energy Agency (IRENA). 2012. Renewable Energy Technologies Cost Analysis Series: Concentrating Solar Power. https://doi.org/10.1016/B978-008-087872-0.00319-X. 


\section{Appendix B. Literature Surveyed for Future CSP LCOE Projections}

This appendix lists our surveyed literature for LCOEs of future CSP projects. Before each reference, in bold text, we indicate the:

- Technology, where:

○ $\mathrm{D}=$ dish Stirling

○ $\mathrm{L}=$ linear Fresnel

○ $\mathrm{P}=$ parabolic trough

○ $\mathrm{T}=$ power tower.

- Country

- Reference number

D-China: Li, Yuqiang, Shengming Liao, Zhenghua Rao, and Gang Liu. 2014. "A Dynamic Assessment Based Feasibility Study of Concentrating Solar Power in China." Renewable Energy 69: 34-42. https://doi.org/10.1016/j.renene.2014.03.024.

D-U.S.: Aabakken, J. 2006. "Power Technologies Energy Data Book-Fourth Edition." NREL/TP-620-39728 . https://doi.org/10.2172/891585.

P-Algeria: Viebahn, Peter, Yolanda Lechon, and Franz Trieb. 2011. "The Potential Role of Concentrated Solar Power (CSP) in Africa and Europe: A Dynamic Assessment of Technology Development, Cost Development and Life Cycle Inventories until 2050.” Energy Policy 39 (8): 4420-30. https://doi.org/10.1016/j.enpol.2010.09.026.

P-Australia: Bedilion, R., G. Booras, C. McGowin, and J. Phillips. 2010. "Australian Electricity Generation Technology Costs: Reference Case 2010." EPRI, Palo Alto, CA and Commonwealth of Australia.

P-China(1): Wang, Zhifeng. 2010. "Prospectives for China's Solar Thermal Power Technology Development." Energy 35 (11): 4417-20. https://doi.org/10.1016/j.energy.2009.04.004.

P-China(2): Li, Yuqiang, Shengming Liao, Zhenghua Rao, and Gang Liu. 2014. "A Dynamic Assessment Based Feasibility Study of Concentrating Solar Power in China." Renewable Energy 69: 34-42. https://doi.org/10.1016/j.renene.2014.03.024.

P-Spain: Viebahn, Peter, Yolanda Lechon, and Franz Trieb. 2011. "The Potential Role of Concentrated Solar Power (CSP) in Africa and Europe: A Dynamic Assessment of Technology Development, Cost Development and Life Cycle Inventories until 2050." Energy Policy 39 (8): 4420-30. https://doi.org/10.1016/j.enpol.2010.09.026.

P-U.S.(1): Sargent \& Lundy. 2003. "Assessment of Parabolic Trough and Power Tower Solar Technology Cost and Performance Forecasts." NREL/SR-550-34440. https://doi.org/10.2172/15005520. 
P-U.S.(2): Turchi, Craig, Mark Mehos, Clifford K Ho, and Gregory J Kolb. 2010. "Current and Future Costs for Parabolic Trough and Power Tower Systems in the US Market." NREL/CP5500-49303. https://www.osti.gov/servlets/purl/991556.

P-Worldwide: Hernández-Moro, J., and J. M. Martínez-Duart. 2013. “Analytical Model for Solar PV and CSP Electricity Costs: Present LCOE Values and Their Future Evolution." Renewable and Sustainable Energy Reviews 20: 119-32. https://doi.org/10.1016/j.rser.2012.11.082.

T-Australia: Bedilion, R., G. Booras, C. McGowin, and J. Phillips. 2010. "Australian Electricity Generation Technology Costs: Reference Case 2010." EPRI, Palo Alto, CA and Commonwealth of Australia.

T-China(1): Wang, Zhifeng. 2010. "Prospectives for China's Solar Thermal Power Technology Development." Energy 35 (11): 4417-20. https://doi.org/10.1016/j.energy.2009.04.004.

T-China(2): Li, Yuqiang, Shengming Liao, Zhenghua Rao, and Gang Liu. 2014. "A Dynamic Assessment Based Feasibility Study of Concentrating Solar Power in China." Renewable Energy 69: 34-42. https://doi.org/10.1016/j.renene.2014.03.024.

T-U.S.(1): Sargent \& Lundy. 2003. "Assessment of Parabolic Trough and Power Tower Solar Technology Cost and Performance Forecasts.” NREL/SR-550-34440. https://doi.org/10.2172/15005520.

T-U.S.(2): Nithyanandam, K., and R. Pitchumani. 2014. "Cost and Performance Analysis of Concentrating Solar Power Systems with Integrated Latent Thermal Energy Storage." Energy 64: 793-810. https://doi.org/10.1016/j.energy.2013.10.095.

T-U.S.(3): Mancini, Thomas R., Jesse A. Gary, Gregory J. Kolb, and Clifford Kuofei Ho. 2011. "Power Tower Technology Roadmap and Cost Reduction Plan." https://doi.org/10.2172/1011644.

T-U.S.(4): Turchi, Craig, Mark Mehos, Clifford K Ho, and Gregory J Kolb. 2010. "Current and Future Costs for Parabolic Trough and Power Tower Systems in the US Market." NREL/CP5500-49303. https://www.osti.gov/servlets/purl/991556. 


\section{Appendix C. Sources for Taxes and Potential Fees on CSP Projects in China}

The following are the sources for Table 1. Taxes and Potential Fees for CSP Projects in China:

[1]. 国家税务总局 State Administration of Taxation. 中华人民共和国企业所得税法

[People's Republic of China Corporate Income Tax Law]. 2007.

[2]. 国家税务总局 State Administration of Taxation. 关于公布公共基础设施项目企业所得税 优惠目录（2008 年版）的通知 [Notice on the Publication of the Corporate Income Tax Preferential Catalogue for Public Infrastructure Projects (2008 Edition)]. 2008.

[3]. 国家税务总局 State Administration of Taxation. 关于实施国家重点扶持的公共基础设施 项目企业所得税优惠问题的通知 [Notice on Implementing the Enterprise Income Tax Preferential Issues for Public Infrastructure Projects Supported by the State]. 2009.

[4]. 国家税务总局 State Administration of Taxation. 关于调整增值税税率的通知 [Notice on adjustingthe VAT rate]. 2018.

[5]. 中华人民共和国能源局 NEA. 国家能源局关于组织太阳能热发电示范项目建设的通知 [Notice of the National Energy Administration on the Organization of Solar Thermal Power Generation Demonstration Projects]. 2015.

[6]. Zhu Z, Zhang D, Mischke P, Zhang X. Electricity Generation Costs of Concentrated Solar Power Technologies in China Based on Operational Plants. Energy. 2015.

[7]. 青海省人民政府 The People's Government of Qinghai Province. 青海省耕地占用税实施 办法 [Implementation Measures for Farmland Occupation Tax in Qinghai Province]. 2009.

[8]. 青海省人民政府 The People's Government of Qinghai Province. 青海省人民政府关于公 布征地统一年产值标准和区片综合地价的通知 [Notice of the People's Government of Qinghai Province on Announcement of the Unified Annual Output Value Standard for Land Acquisition and the Comprehensive Land Price of the District]. 2016.

[9]. 青海省海西蒙古族藏族自治州人民政府 People’s Government of Haixi Mongolian Tibetan Autonomous Prefecture Qinghai Province. 德令哈光伏发电应用领跑基地竞争优选工 作方案 [Delingha Photovoltaic Power Generation Application Leading Base Competition Optimization Work Plan]. 2018.

[10]. 海西州国土资源局 Haixi Land and Resources Bureau. 海西州国土资源局关于德令哈市 2015 年度第十四批次城市建设用地的审查意见 [Review of Haixi Prefecture Land and Resources Bureau on the 14th Batch of Urban Construction Land in Delingha City in 2015]. 2015. 
[11]. 青海省人民政府 The People's Government of Qinghai Province. 关于我省草原植被恢复 费收费标准及有关事项的通知 [Notice on the Charging Standards and Related Matters of Grassland Vegetation Restoration Fees in Our Province]. 2018.

[12]. EnergyTrend. 青海领跑者土地费用前后说法变化的五个阶段 [Five Stages of Changes in the Land Cost of Solar PV Leadership Program in Qinghai]. 2018. 


\section{Appendix D. Sources for Cost Inputs Used for SAM Simulation}

The following are the sources for Table 2: Cost Inputs Used for SAM Simulation, Compared with the SAM Reference Case Parabolic Trough Plant:

[1]. Kurup P., Turchi C. S. Parabolic Trough Collector Cost Update for the System Advisor Model (SAM). 2015.

[2]. Li X, Zhao X, Li J, LI W, Xu N, Huang W. 塔式太阳能热发电全寿命周期成本电价分析 [Analysis of Life-Cycle Levelized Cost of Electricity for Tower Solar Thermal Power]. Automation of Electric Power Systems. 2015.

[3]. Turchi C. Concentrating Solar Power : Current Cost and Future Directions. 2017.

[4]. Turchi C, Heath GA. Molten Salt Power Tower Cost Model for the System Advisor Model (SAM). National Renewable Energy Laboratory. 2013.

[5]. Zhao Z-YY, Chen Y-LL, Thomson JD. Levelized Cost of Energy Modeling for Concentrated Solar Power Projects: A China Study. Energy. 2017.

[6]. Turchi C. Parabolic Trough Reference Plant for Cost Modeling with the Solar Advisor Model (SAM). 2010.

[7]. 国网能源研究院 SGERI. 中国光热发电市场潜力研究[Research on the Potential of China's CSP Market]. 2013.

[8]. Li Y, Liao S, Rao Z, Liu G. A Dynamic Assessment Based Feasibility Study of Concentrating Solar Power in China. Renew Energy. 2014.

[9]. 西宁市发展和改革委员 Xining Development and Reform Commission. 西宁市发展和改 革委员会关于调整西宁市非居民用天然气销售价格的通知 [Notice of the Xining Development and Reform Commission on Adjusting the Sales Price of Non-Resident Natural Gas in Xining City]. 2015.

[10]. Turchi C, Mehos M, Ho CK, Kolb GJ. Current and Future Costs for Parabolic Trough and Power Tower Systems in the US Market. 2010.

[11]. International Monetary Fund. World Economic Outlook. IMF. 2018.

[12]. System Advisor Model (SAM) Default Value. National Renewable Energy Laboratory. 2018. 